Stjepan Gadžo*

Pregledni znanstveni rad

UDK 334.726:336.22

338.246(4-67 EU)

DOI: https://doi.org/10.25234/pv/6283

Rad primljen: 7. siječnja 2018.

\title{
OPOREZIVANJE DOBITI MULTINACIONALNIH KOMPANIJA I PRAVO DRŽAVNIH POTPORA EUROPSKE UNIJE: STUDIJA “SLUČAJA APPLE”**
}

Sažetak: U ovom se radu iznosi analiza najvažnijih pravnih aspekata odluke Europske komisije u slučaju Apple, s posebnim naglaskom na međuodnos prava državnih potpora EU-a i diskrecijskog postupanja poreznih tijela država članica pri oporezivanju multinacionalnih kompanija. Predmetna odluka, donesena u kolovozu 2016. godine, izaziva niz prijepora, posebno u vezi s inovativnim tumačenjem pravnog statusa tzv. načela neovisnosti i pravila o transfernim cijenama unutar EU-a. Konačni će pravorijek o valjanosti pravnih i činjeničnih nalaza Komisije u ovom predmetu donijeti Sud EU-a kao jedini ovlašteni tumač prava Unije. Posebno je važno predmetnu odluku razmotriti u širem društvenopolitičkom kontekstu. Naime, pravila EU-a o državnim potporama u posljednjim se godinama počinju shvaćati kao instrument za sprječavanje tzv. agresivnog poreznog planiranja te postizanje "pravednijeg" oporezivanja multinacionalnih kompanija. Iz perspektive većeg broja država članica novi aktivizam institucija EU-a u ovom području predstavlja potencijalno značajnu ugrozu njihova poreznog suvereniteta, npr. u vodenju politike poreznih izdataka. Stoga temeljni nalazi ovog rada mogu biti od višestruke koristi za znanstvenike i praktičare iz srodnih područja poreznog prava i prava državnih potpora.

Ključne riječi: $\quad$ pravo državnih potpora, Apple, porez na dobit, obvezujuća porezna mišljenja, transferne cijene, međunarodno porezno pravo

\footnotetext{
Dr. sc. Stjepan Gadžo poslijedoktorand je na Katedri za financijsko pravo Pravnog fakulteta Sveučilišta u Rijeci, Hahlić 6, 51000 Rijeka, Republika Hrvatska. Adresa e-pošte: sgadzo@pravri.hr. ORCID: https://orcid.org/0000-0002-1905-5330.

** Ovaj je rad nastao uz potporu Hrvatske zaklade za znanost u okviru projekta br. 9366, "Pravni aspekti korporativnih akvizicija i restrukturiranje trgovačkih društava utemeljenih na znanju".
} 


\section{UVOD}

Europska komisija (dalje: EK) je 30. kolovoza 2016. donijela odluku u tzv. predmetu Apple. Njome je utvrđeno da je Republika Irska Apple ${ }^{1}$ grupi dodijelila državnu potporu okvalificiranu nezakonitom u svjetlu čl. 107., st. 1. Ugovora o funkcioniranju Europske unije (dalje: UFEU), ${ }^{2}$ i to u obliku određenih poreznih pogodnosti, čiji se iznos procjenjuje na čak 16 mlrd. EUR. ${ }^{3}$ Imajući u vidu visinu ovog iznosa, čiji povrat irske vlasti moraju zahtijevati od Applea, kao i činjenicu da je riječ o najvećoj svjetskoj multinacionalnoj kompaniji (dalje: $\mathrm{MNK}^{4}$ ) prema kriteriju tržišne kapitalizacije, ${ }^{5}$ predmetna je odluka izazvala žustre rasprave na globalnoj razini. Pritom je pod povećalom ne samo pravni supstrat odluke, nego i njezini širi društveni i politički učinci, napose u vezi s poslovanjem MNK-a na unutarnjem tržištu EU-a te trgovinskih odnosa između Unije i SAD-a. ${ }^{6}$

Predmetna odluka, kao i postupci EK-a u drugim srodnim predmetima, ${ }^{7}$ predstavlja tek najnoviji moment u višegodišnjim naporima institucija EU-a za reformama mehanike oporezivanja MNK-a, s ciljem pravednije raspodjele ukupnog poreznog opterećenja. ${ }^{8}$ Naime, fenomen porezne evazije, povezan s tehnikama međunarodnog poreznog planiranja, postaje prvorazredno političko pitanje nakon izbijanja posljednje globalne ekonomske krize. ${ }^{9}$ Većina je država stoga, bar deklarativno, objavila rat tzv. agresivnom poreznom planiranju MNK-a te su po-

1 Odluka Komisije (EU) 2017/1283 od 30. kolovoza 2016. o državnoj potpori SA.38373 (2014/C) (ex 2014/NN) (ex 2014/CP) koju je provela Irska za društvo Apple, SL L 187, od 19. srpnja 2017., str. 1.-110. (dalje: Odluka EK-a).

2 Najnovija pročišćena verzija UFEU-a objavljena je u SL C 202, od 7. lipnja 2016., str. 1.-388.

3 Detaljnije v. infra, poglavlje 4.

4 Pojam multinacionalnih kompanija nije jednoznačan. Polazeći od strukturnih obilježja MNK možemo pojmovno odrediti kao "integrirano ili centralizirano poslovanje (...) (S)astoji se od dva ili više poduzeća pod zajedničkom kontrolom, sa zajedničkim resursima i zajedničkim ciljevima, s jedinicama poslovanja smještenim u više država" (Eden, L., Taxing Multinationals: Transfer Pricing and Corporate Income Taxation in North America, University of Toronto Press, Toronto, 1998., str. 126.). Usp. i: Arbutina, H., Ott K., Porezni leksikon s višejezičnim rječnikom: engleski, hrvatski, francuski, njemački, španjolski, Institut za javne financije, Zagreb, 1999., str. 228.

5 U vrijeme pisanja ovog rada tržišna se vrijednost Applea procjenjuje na 794,5 mlrd. USD. Vidjeti http://www.nasdaq.com/ symbol/aapl. Pristupljeno 3. listopada 2017.

6 Vidjeti npr. U. S. Department of the Treasury, The European Commission's recent state aid investigations of transfer pricing rulings (white paper), dostupno na: https://www.treasury.gov/connect/blog/Pages/Treasury-Releases-White-Paper-on-European-Commission\%E2\%80\%99s-State-Aid-Investigations-into-Transfer-Pricing-Rulings.aspx. Pristupljeno 10. listopada 2017.; Maitrot de la Motte, A., The Recovery of the Illegal Fiscal State Aids: Tax Less to Tax More, EC Tax Review, vol. 26., br. 2/2017., str. 75.-88.; Fleming, J. C., The EU Apple Case: Who Has a Dog in the Fight?, Tax Notes, vol. 154, br. 2/2017, str. 251.-256.; Cachia, F., Analysing the European Commission's Final Decisions on Apple, Starbucks, Amazon and Fiat Finance \& Trade, EC Tax Review, vol. 26, br. 1/2017., str. 23.-35.

7 Posebno v. Odluka Komisije (EU) 2016/2326 od 21. listopada 2015. o državnoj potpori SA.38375 (2014/C ex 2014/NN) koju je dodijelio Luksemburg u korist društva Fiat, OJ L 351, 22. 12. 2016, str. 1.-67.; Odluka Komisije (EU) 2017/502 od 21. listopada 2015. o državnoj potpori SA.38374 (2014/C, ex 2014/NN) koju je Nizozemska provela u korist Starbucksa, SL L 83, 29. 3. 2017., str. 38.-115.; Odluka Komisije (EU) 2016/1699 od 11. siječnja 2016. o programu državnih potpora u pogledu izuzeća od oporezivanja viška dobiti SA.37667 (2015/C) (ex 2015/NN) koji je provela Belgija, SL L 260, 27. 9. 2016., str. 61.-103

8 Usp. Lovdahl Gormsen, L., EU State Aid Law and Transfer Pricing: A Critical Introduction to a New Saga, Journal of European Competition Law \& Practice, vol. 7, br. 6, 2016., str. 369. O pojmu pravednosti u kontekstu međunarodnog oporezivanja v. Gadžo, S., Prilog istraživanju sadržaja načela pravednosti kao kriterija evaluacije normi međunarodnog poreznog prava, Pravni vjesnik, vol. 31, br. 2, str. 131.-156.

9 Za pojam i osnovne pojavne oblike poreznog planiranja v. Gadžo, S., Nematerijalna imovina multinacionalnih korporacija u kontekstu međunarodnog poreznog prava. Zbornik Pravnog fakulteta u Zagrebu, vol. 65, br. 5, 2015., str. 743.-773. Koncept agresivnog poreznog planiranja u literaturi se najčešće izjednačava sa zakonitim izbjegavanjem poreza (engl. tax avoidance), tj. umanjenjem poreznog opterećenja u skladu sa slovom propisa, ali suprotno namjeri zakonodavca. Usp.: Rogić Lugarić, T., Bogovac, J., Poreznopravni aspekti poreznih izdataka, Hrvatska i komparativna javna uprava, vol. 13, br. 4, 2013., str. 1143.-1144. 
segnule za određenim zakonodavnim protumjerama, dio kojih je koordiniran is međunarodne razine, pogotovo u okviru Organizacije za ekonomsku suradnju i razvoj (dalje: OECD). Upravo je zajednički projekt OECD-a i skupine G20, usmjeren sprječavanju erozije porezne osnovice i premještanja dobiti (engl. Base Erosion and Profit Shifting; dalje: BEPS projekt), započet 2013. godine, rezultirao značajnim izmjenama međunarodnih porezno-pravnih normi, dio kojih je utjelovljen i u novoj multilateralnoj konvenciji. ${ }^{10}$

Za razumijevanje pravne dimenzije "slučaja Apple" ključno je podcrtati da primarno pravo EU-a institucijama Unije ostavlja veoma ograničene ovlasti na području oporezivanja dobiti trgovačkih društava, pa je tako i njihov instrumentarij za borbu protiv agresivnog poreznog planiranja relativno siromašan. U tom kontekstu sve veći značaj dobivaju ovlasti EK-a u području državnih potpora (engl. state aids). Iako je utjecaj prava državnih potpora na porezne sustave država članica prepoznat i znatno prije, do novog zamaha dolazi nakon 2014. godine. Ukratko, EU-ova pravila o državnim potporama počinju se shvaćati kao adekvatan instrument za sprječavanje onih tehnika agresivnog poreznog planiranja koje se oslanjaju na različite porezne pogodnosti (porezne izdatke) propisane u unutarnjem pravu država članica. ${ }^{11}$ Promatrano iz ovog kuta, odgovornost za nepravedne i/ili neučinkovite rezultate oporezivanja MNK-a ne može svaliti isključivo na porezne obveznike (pasivne porezne subjekte), nego i na same države (aktivne porezne subjekte) koje, u okviru svoje suverene vlasti, kreiraju i provode porezno-pravna pravila. ${ }^{12}$

U ovom se radu iznosi analiza najvažnijih pravnih aspekata slučaja Apple, s posebnim naglaskom na međuodnos prava državnih potpora EU-a i diskrecijskog postupanja poreznih tijela država članica pri oporezivanju MNK-a. Rezultati analize mogu, s obzirom na neprijeporni politički značaj predmetnog slučaja te kompleksna pravna pitanja koje otvara, biti od višestruke koristi za znanstvenike i praktičare iz srodnih područja poreznog prava i prava državnih potpora.

Rad je u strukturnom smislu podijeljen na šest temeljnih cjelina (poglavlja). Nakon uvoda, u drugom se poglavlju ukratko izlažu osnove međuodnosa EU-ovih pravila o državnim potporama i poreznog prava država članica. U trećem se poglavlju u sažetom obliku prikazuje Appleova porezna strategija, tj. ukupnost različitih tehnika poreznog planiranja s pomoću kojih je ukupno porezno opterećenje ovog poduzeće drastično sniženo. Četvrto poglavlje sadrži prikaz temeljnih pravnih i činjeničnih nalaza iznesenih u odluci EK-a u "slučaju Apple”. U petom se poglavlju analiziraju osnovni pravni prijepori koji proizlaze iz predmetne odluke, a koji će biti razriješeni u judikaturi Suda Europske unije. Rad završava zaključkom, u kojem se komentira značaj predmetne odluke za buduća kretanja u međunarodnom i europskom poreznom pravu.

Općenito o pristupu EK-a problemu agresivnog poreznog planiranja v. Mijatović, N., Pošteno oporezivanje: nove mjere Europske komisije za borbu protiv porezne utaje, Porezni vjesnik, br. 4/2016.

10 Općenito o BEPS projektu v. Martinović, Ž., Ključne točke OECD-ova Akcijskog plana o eroziji porezne osnovice i alokaciji profita (Base Erosion and Profit Shifting - BEPS, Porezni vjesnik, br. 10/2015, str. 100.-112. O multilateralnom ugovoru, čiji je cilj što brža i jednostavnija implementacija preporuka BEPS projekta u postojeću mrežu ugovora o izbjegavanju dvostrukog oporezivanja (porezni ugovori), v. http://www.oecd.org/tax/treaties/multilateral-convention-to-implement-tax-treaty-related-measures-toprevent-beps.htm. Pristupljeno: 10. studenog 2017.

11 Vidjeti Rossi-Maccanico, P., Fiscal State Aids, Tax Base Erosion and Profit Shifting, EC Tax Review, vol. 24, br. 2, 2015., str. 64.

12 Usp. Ault, H. J., Schön, W., Shay, S. E., Base Erosion and Profit Shifting: A Roadmap for Reform, Bulletin for International Taxation, vol. 68, br. 6-7/2014., str. 276.; Owens, J., The Taxation of Multinational Enterprises: An Elusive Balance, Bulletin for International Taxation, vol. 67, br. 8/2013., str. 442.-443. 


\section{OPĆENITO O ODNOSU PRAVA DRŽAVNIH POTPORA EU-A I POREZNOG SUVERENITETA DRŽAVA ČLANICA}

Temelji normativnog okvira državnih potpora u EU-u postavljeni su u primarnom pravu EU-a, preciznije u čl. 107.-109. UFEU-a. Od ključnog je značaja čl. 107., st. 1. UFEU-a, koji postavlja opće kriterije (atribute) nezakonitih državnih potpora, tj. potpora nespojivih s načelima unutarnjeg tržišta EU-a. ${ }^{13}$ Sukladno ustaljenoj praksi Suda Europske unije (dalje: Sud EU-a), ali i prevladavajućem stavu pravne znanosti, navedenu odredbu valja tumačiti tako da su zabranjene one državne potpore koje ispunjavaju četiri kumulativna uvjeta: 1) da je riječ o mjeri kojom se nekim poduzetnicima (korisnicima) dodjeljuje određena ekonomska prednost; 2) da je prednost dana od države članice ili kroz državna sredstva u bilo kojem obliku, tj. da predstavlja financijsko opterećenje za javnu vlast; 3 ) da je mjera u pitanju selektivna, tj. da prednost uživa samo određeni poduzetnik ili proizvod; 4) da se davanjem takve prednosti barem potencijalno narušava tržišno natjecanje i utječe na međudržavnu trgovinu unutar EU-a. ${ }^{14}$

Judikatura Suda EU-a potvrdila je široki pojmovni obuhvat državnih potpora te se one ne odnose samo na izravne novčane transfere i/ili jamstva koje poduzetnici dobivaju od javne vlasti. ${ }^{15}$ Naime, s obzirom na temeljni gospodarski učinak svakog poreza - smanjenje gospodarske snage (imovine) poreznih obveznika uz odgovarajuće povećanje gospodarske snage države - pojmom "zabranjenih državnih potpora" moguće je obuhvatiti i pojedine mjere porezne politike država članica, tj. elemente njihovih poreznih sustava. Predmetne se mjere mogu zajednički označiti pojmom "poreznih izdataka" (engl. tax expenditures), s obzirom na to da nužno podrazumijevaju niže porezno opterećenje fizičkih/pravnih osoba s jedne strane te gubitak (potencijalnih) poreznih prihoda za javnu vlast s druge. ${ }^{16}$

Europska je komisija 1998. godine započela s detaljnijom analizom nacionalnih sustava oporezivanja dobitka kroz prizmu prava državnih potpora EU-a. ${ }^{17}$ Pritom je pojašnjen način na koji gore navedene kriterije iz čl. 107., st. 1. UFEU-a valja primjenjivati kad je riječ o porezima. Prvo su razložena tri osnovna načina na koji se može smanjiti porezno opterećenje poduzetnika i tako im dodijeliti ekonomsku prednost: a) smanjenje porezne osnovice (npr. preko posebnih olakšica, ubrzane amortizacije i sl.); b) potpuno ili djelomično smanjenje iznosa poreznog duga (npr. potpuno ili djelomično porezno oslobođenje ili odbitak od poreza); c) priznanje posebnih pogodnosti pri naplati poreznog duga (npr. odgoda plaćanja, reprogram

13 Detaljnije v. Petrović, S., Liszt, M., Kriteriji za dodjelu dopuštenih državnih potpora, u: Čulinović Herc, E. et al. (ur.), Financiranje, upravljanje i restrukturiranje trgovačkih društava u vrijeme recesije, Rijeka, Pravni fakultet Sveučilišta u Rijeci, 2011., str. 27.-68.; Lang, M., State Aid and Taxation: Selectivity and Comparability Analysis, u: Richelle, I., et al. (ur.), State Aid Law and Business Taxation, Springer, Berlin, 2016., str. 27.-28.

14 Detaljnije v. Mamut, M. A., The State Aid Provisions of the TFEU in Tax Matters, u: Lang, M., et al. (ur.), Introduction to European Tax Law on Direct Taxation, Linde, Beč, 2010., str. 82.-96.

15 Vidjeti npr. presudu Suda EU-a od 23. veljače 1961., Gezamenlijke Steenkolenmijnen, Case 30/59, EU:C:1961:2.

16 O pojmu poreznih izdataka detaljnije v. Bratić, V., Porezni izdaci: teorijski pregled, Financijska teorija i praksa, vol. 30, br. 2, 2006. str. 113.-127.; Luja, R. H. C., Assessment and recovery of tax incentives in the EC and the WTO: a view on state aids, trade subsidies and direct taxation, Intersentia, Antwerpen, 2003., str. 8.-10.

17 Vidjeti Europska komisija (1998), Obavijest Komisije o primjeni propisa o državnim potporama na mjere koje se odnose na izravno oporezivanje poduzetrika, SL C 384, 10. 12. 1998., str. 3.-9. 
ili otpis poreznog duga). ${ }^{18}$ Drugo, pojašnjeno je da kriterij davanja potpore "preko državnih sredstava" uključuje svaki gubitak poreznih prihoda koji bi bili prikupljeni da nije bilo davanja prednosti preko predmetnih poreznih propisa ili postupaka poreznih tijela. Treće, obrazloženo je da će kriterij “utjecaja na tržišno natjecanje i međudržavnu trgovinu EU-a” biti veoma lako ispunjen jer je dovoljno da poduzetnik u pitanju obavlja kakvu gospodarsku djelatnost koja uključuje trgovinu između država članica. ${ }^{19}$ Naposljetku je Komisija analizirala primjenu kriterija selektivnosti na porezne izdatke te je zaključeno da mora postojati određeno odstupanje od "opće sheme poreznog sustava" u korist određenih poduzetnika u državi članici.

EK je već u navedenom dokumentu naznačio kako će u praktičnoj primjeni prava državnih potpora na porezne izdatke od presudne važnosti biti analiza selektivnosti promatrane mjere. Isto je potvrđeno i u kasnijoj praksi Suda EU-a. ${ }^{20} \mathrm{U}$ poreznim slučajevima test selektivnosti u načelu se sastoji od tri susljedna koraka: (i) najprije valja utvrditi referentni porezno-pravni sustav; (ii) zatim valja utvrditi predstavlja li mjera u pitanju odstupanje od referentnog sustava u obliku različitog tretmana poduzetnika usporedivih i u pravnom i u činjeničnom smislu; (iii) konačno, ako se utvrdi odstupanje, mora se utvrditi je li mjera opravdana u svjetlu prirode ili opće sheme referentnog sustava. ${ }^{21}$ Prevladavajuće je stajalište literature, temeljeno na analizi prakse EK-a i Suda EU-a, kako test selektivnosti zapravo počiva na komparaciji poreznog tretmana koji proizlazi iz odstupanja od općeg sustava s poreznim tretmanom kojeg propisuje opći sustav. ${ }^{22}$ Ako je zaključak takve analize da jedna kategorija subjekata može računati na pogodniji tretman u odnosu na drugu kategoriju subjekata, usporedivu i u činjeničnom i u pravnom smislu, onda je mjera u pitanju prima faciae selektivna. Međutim, ni tada se neće raditi o zabranjenoj državnoj potpori ako je nejednaki tretman opravdan s obzirom na inherentnu logiku i/ili strukturu referentnog porezno-pravnog sustava. ${ }^{23}$

Iz izloženoga je vidljivo kako je za primjenu testa selektivnosti ključno odrediti referentni porezno-pravni sustav. ${ }^{24}$ Neprijeporno njegove vanjske granice valja tražiti unutar granica cjelokupnog poreznog sustava države članice u pitanju. Međutim, prostor za utvrđenje nejednakog tretmana uvelike se smanjuje što je uži referentni okvir; primjerice, u slučaju propisivanja povoljnijeg poreznog tretmana kamata koje rezidenti primaju iz inozemstva u odnosu na kamate iz tuzemstva, utvrđenje prima faciae selektivnosti bit će otežano ako se referentni okvir ograniči isključivo na pravila o oporezivanju dohotka iz inozemstva; s druge strane, ako se za referentni okvir odredi opći sustav oporezivanja dohotka/dobiti, utvrđenje selektivnosti vrlo je vjerojatno. ${ }^{25}$

\footnotetext{
18 Ibid., str. 10. Usp. Terra, B., Wattel, P. J., European Tax Law, Kluwer Law International, 2012., str. 244.

Vidjeti Europska komisija, op. cit., u bilj. 17, str. 10

21 Vidjeti detaljnije Micheau, C., State Aid and Taxation in EU Law, u: E. Szyszczak (ur.), Research Handbook on European State Aid Law, Edward Elgar, Cheltenham, 2011., str. 201.-204.

22 Ibid., str. 202.; Lang, op. cit., u bilj. 13, str. 35.-36.

23 Vidjeti Micheau, op. cit., u bilj. 21, str. 202.-203. 
U tom smislu posebno je značajno da u novijem dokumentu posvećenom primjeni prava državnih potpora EK jasno navodi kako se referentni sustav načelno podudara s općim sustavom nametanja i ubiranja pojedinog poreznog oblika. Drugim riječima, referentni sustav najčešće će činiti korpus općih pravila koja se primjenjuju na sve obveznike poreza na dobit (pravila o poreznoj osnovici, poreznoj stopi i dr.). ${ }^{26}$ Za potrebe ovog rada posebno je važno istaknuti stav Komisije da načelo neovisnosti, utjelovljeno u čl. 9. OECD-ova modela ugovora o izbjegavanju dvostrukog oporezivanja, čini dio referentnog sustava za analizu poreznog tretmana povezanih društava, tj. MNK-a. ${ }^{27}$

U svjetlu gore oslikane skice međuodnosa prava državnih potpora EU-a i nacionalnih poreznih sustava, ne treba čuditi negativan stav mnogih država članica o sve ekstenzivnijoj primjeni pravila državnih potpora u ovom području, posebno nakon 2014. godine. Naime, iz perspektive država članica ovaj novi aktivizam EK-a predstavlja potencijalno značajnu ugrozu njihova suvereniteta u poreznim stvarima, npr. u vođenju politike poreznih izdataka (vidi supra). Vrijedi naglasiti da u postojećem modelu raspodjele ovlasti između država članica i institucija EU-a, potonje imaju veoma ograničenu ulogu kad je riječ o neposrednim (izravnim) porezima, poput poreza na dohodak i poreza na dobit. Međutim, pod egidom zaštite unutarnjeg tržišta institucije Unije postavljaju određena ograničenja pred nacionalne nositelje porezne politike. Tako primjerice određeni element nacionalnog poreznog sustava ili kakvo postupanje poreznih tijela može biti kvalificirano protivnim kojoj od temeljnih tržišnih sloboda EU-a, ali i kao zabranjena državna potpora. ${ }^{28}$

\subsection{OBVEZUJUĆA POREZNA MIŠLJENJA KAO ZABRANJENE DRŽAVNE POTPORE}

Među postupanjima poreznih tijela koji podliježu kontroli s aspekta prava državnih potpora EU-a važnu ulogu zauzimaju tzv. obvezujuća porezna mišljenja (engl. advance tax rulings). ${ }^{29}$ Iako ne postoji jedinstvena definicija ovog instituta, s obzirom na njegove raznolike pojavne oblike u komparativnim poreznim sustavima, obvezujuće je porezno mišljenje najčešće upravni akt koji izdaje porezno tijelo i kojim se ono obvezuje slijediti određeni pristup pri primjeni poreznih propisa na transakcije, poslove i/ili druge porezno relevantne činjenice određenog poreznog obveznika, i to prije nastanka tih činjenica. Drugim riječima, porezno tijelo, na temelju prethodnog formalnog zahtjeva poreznog obveznika, u obvezujućem mišljenju izlaže kakav bi bio porezni tretman budućih, namjeravanih poslova/aktivnosti poreznog obveznika te je dužno pridržavati se izloženog ako se i kada ti poslovi/aktivnosti doista i realiziraju. ${ }^{30}$ U tom smislu obvezujuća se mišljenja u teoriji prepoznaju kao jedan od temeljnih instituta

26 Vidjeti Europska komisija (2016), Obavijest Komisije o pojmu državne potpore iz članka 107. stavka 1. Ugovora o funkcioniranju Europske unije, SL C 262, 19. 7. 2016., para. 133.-134.

27 Vidjeti ibid., para. 172. Općenito o načelu neovisnosti i korpusu pravila o transfernim cijenama v. Gadžo, op. cit., u bilj. 9, str. 752.- 755

28 Vidjeti Terra, Wattel, op. cit., u bilj. 18, str. 243.-244.; Engelen, F., State Aid and Restrictions on Free Movement: Two Sides of the Same Coin?, European Taxation, vol. 52, br. 5/2012., str. 206.

30 O pojmu ovog instituta poreznog prava v. detaljnije u: Žunić Kovačević, N., Prethodna obvezujuća porezna mišljenja - novi institut hrvatskog poreznog postupka, Zbornik Pravnog fakulteta Sveučilišta u Rijeci, vol. 37, br. 1/2016., str. 268.-273. 
poreznog prava usmjerenih na jačanje pravne sigurnosti sudionika porezno-pravnog odnosa, posebno poreznih obveznika. ${ }^{31}$

Iako praksa izdavanja obvezujućih mišljenja ne predstavlja povredu pravila o državnim potporama per se, EK je već 1998. upozorio da takve administrativne mjere mogu biti selektivne, tj. rezultirati davanjem prednosti isključivo poreznom obvezniku koji je adresat mišljenja. ${ }^{32}$ Primjena prava državnih potpora EU-a na obvezujuća mišljenja izdana od strane poreznih tijela država članica postaje prvorazredno pitanje tek nakon 2013. godine, kad EK započinje opsežnu istragu, u jeku afere Luxembourg Leaks (vidjeti infra, poglavlje 4.1.). Do kraja 2014. godine sve su države članice koje u svojem unutarnjem pravu predviđaju institut obvezujućeg mišljenja morale Komisiji dostaviti podatke o svim relevantnim aktima izdanim u razdoblju 2010.-2013. ${ }^{33}$

Slučajevi u kojima je Europska komisija pokrenula formalne postupke kontrole državnih potpora pretežito se tiču jednog posebnog podoblika obvezujućih mišljenja - tzv. prethodnih sporazuma o transfernim cijenama (engl. advance pricing agreement; dalje: APA sporazumi). Ukratko, riječ je o aktima koji utjelovljuju sporazum između poreznog obveznika (najčešće multinacionalne korporacije) i poreznog tijela o kriterijima prema kojima će se pravila o transfernim cijenama primjenjivati na unutargrupne transakcije/odnose poreznog obveznika, unutar određenog budućeg vremenskog okvira. ${ }^{34}$ S obzirom na to da se APA sporazumi temelje na modelu suradnje i dijaloga između poreznih tijela i poreznih obveznika, ${ }^{35}$ njihova glavna prednost leži u umanjenju poreznih rizika i troškova za sve dionike te u izbjegavanju potencijalno dugotrajnih i neizvjesnih sporova. ${ }^{36}$ To je posebno značajno ako se ima u vidu složenost problematike transfernih cijena, koja zauzima prvorazredno značenje pri poslovanju MNK-a, ujedno i najvećih poreznih obveznika. ${ }^{37}$

U praksi EK-a prije 2013. već su naznačene osnovne smjernice kojih su se porezna tijela država članica dužna pridržavati pri izdavanju APA sporazuma, u svjetlu prava državnih potpora. Prvotno valja naglasiti stav EK-a, potvrđen i u judikaturi Suda EU-a, da pri donošenju takvih akata porezna tijela država članica ne smiju odstupati od načela neovisnosti jer se inače poreznim obveznicima u pitanju dodjeljuje selektivna prednost. ${ }^{38}$ Dodatno, EK se bavio

31 Vidjeti ibid., str. 273.

32 Vidjeti Europska komisija, op. cit., u bilj. 17, str. 163.

33 Luja, R. H. C., Will the EU's State Aid Regime Survive BEPS?, British Tax Review, br. 3/2015., str. 383.-384.

34 Vidjeti OECD (2017), OECD Transfer Pricing Guidelines for Multinational Enterprises and Tax Administrations 2017, OECD Publishing, Paris, str. 214. Za novije komparativne podatke o dostupnosti APA sporazuma v. detaljnije: Deloitte (2016), 2016 Global Transfer Pricing Country Guide, dostupno na: https://www2.deloitte.com/us/en/pages/tax/articles/global-transferpricing-country-guide.html. Pristupljeno 1. studenog 2017.

35 Općenito o različitim modelima porezno-pravnog odnosa v. Rogić Lugarić, T., Porezna tijela i porezni obveznici: od policajca i lopova do suradnika, u: Koprić, I.; Musa, A.; Giljević, T. (ur.), Građani, javna uprava i lokalna samouprava: povjerenje, suradnja, potpora, Institut za javnu upravu, Zagreb, 2017., str. 341.-362.

36 Vidjeti Kerschner, I., Stiastny, M., The Experience with Advance Pricing Agreements, Intertax, vol. 41, br. 11/2013., str. 588.-593.

37 Među poreznim je stručnjacima poznata maksima kako se primjena pravila međunarodnog poreznog prava u praksi dijeli na "transferne cijene i sve ostalo". Prema: Li, J., Global profit split: An evolutionary approach to international income allocation, Canadian Tax Journal, vol. 50, br. 3/2002., str. 854.-855.

38 Posebno vidjeti presudu Suda EU-a od 22. lipnja 2006., Kingdom of Belgium (C-182/03) and Forum 187 ASBL (C-217/03) v Commission of the European Communities, EU:C:2006:416, ECR 2006 I-05479, para. 95. Usp. i Europska komisija, op. cit., u bilj. 26, str. 37. 
i mnogo konkretnijim pitanjima metodologije transfernih cijena koje su utjelovljene u APA sporazumima. U vezi s tim EK polazi od preporuka sadržanih u OECD-ovim Smjernicama o transfernim cijenama (dalje: OECD Smjernice). ${ }^{39}$ Tako je u nizu odluka EK-a primjerice utvrđeno da pojam “zabranjene državne potpore” uključuje i APA sporazume koji polaze od fiksnih marži pri primjeni metoda dodavanja bruto-dobitka na troškove (engl. cost-plus method) ili predviđaju primjenu metode trgovačkih cijena (engl. resale price method) iako su bile dostupne i druge, izravnije metode za utvrđivanje prikladnih transfernih cijena. ${ }^{40}$

\section{APPLEOVA POREZNA STRATEGIJA: 1991. - 2015.}

Apple je multinacionalna kompanija čiji začeci sežu u 70-e godine 20. stoljeća i vezani su za inicijativu informatičkih stručnjaka Stevea Jobsa i Stevea Wozniaka. Današnje poslovanje Apple grupe temelji se na proizvodnji i prodaji stolnih i prijenosnih računala (Mac linija proizvoda), telekomunikacijskih uređaja (npr. iPhone), drugih platformi za prikazivanje audiovizualnih sadržaja (npr. iPad, Apple Watch), kao i na razvoju i ustupu na korištenje programske podrške (softvera) te pružanju drugih digitalnih usluga (npr. aplikacija iTunes, iCloud). Velika ulaganja u istraživanje i razvoj te vertikalna integracija poduzeća ključ su Appleova poslovnog modela, na čiji besprimjerni uspjeh ukazuje kontinuirani godišnji rast prihoda od prodaje i ukupne neto dobiti. ${ }^{41}$ Kupci i korisnici Appleovih proizvoda i usluga su poduzetnici, državna tijela i agencije, subjekti iz neprofitnog sektora te krajnji potrošači iz cijelog svijeta. S obzirom na kriterij prostorne određenosti kupaca/korisnika, globalno tržište Applea dijeli se na pet glavnih geografskih segmenata: 1) područje Sjeverne i Južne Amerike, 2) područje Europe, Afrike, Bliskog istoka i Indije, 3) područje Kine, Hong Konga i Tajvana, 4) područje Japana te 5) područje Australije te ostalih država azijsko-pacifičke regije. ${ }^{42}$ U 2015. je godini grupa imala više od 100.000 zaposlenika, od čega je 60.000 ljudi bilo zaposleno u SAD-u.

\subsection{APPLE GRUPA: ORGANIZACIJSKA STRUKTURA I POREZNO PRAVO}

Organizacijska struktura Apple grupe veoma je kompleksna i obuhvaća veći broj povezanih društava osnovanih u nizu država. Krovno društvo je Apple Inc., osnovano prema pravu SAD-a i sa sjedištem u Kaliforniji. Za potrebe ovog rada od posebne je važnosti analiza onog dijela organizacijske strukture grupe koji se odnosi na tržišni segment u Europi, Africi, Bliskom istoku i Indiji.

Temelji današnje organizacijske strukture grupacije postavljeni su 1980. godine, netom prije prvog uvrštenja Appleovih dionica na njujoršku burzu (NYSE). Tada se, naime, s ciljem 
jačeg prodora na europsko tržište, u Irskoj osniva nekoliko zavisnih društava, od kojih su najvažnija Apple Operations International (AOI), Apple Operations Europe (AOE) i Apple Sales International (ASI). ${ }^{43}$

AOI je holding društvo, u čijem su vlasništvu udjeli svih ostalih povezanih društava Apple grupe osnovanih u drugim državama. U biti riječ je o fiktivnom društvu, "ljušturi" (engl. shell company $)^{44}$ bez zaposlenika, materijalne imovine ili bilo kakvih drugih manifestacija fizičke prisutnosti u Irskoj, državi prema čijem je pravu osnovano. Upravu AOI-a čine zaposlenici krovnog društva Apple Inc.-a, koji žive u SAD-u te su se i sastanci uprave odvijali isključivo izvan Irske, tj. na teritoriju SAD-a. Potonja činjenica je ključna za uspjeh globalne porezne strategije. Naime, AOI ni u jednom trenutku u porezno-pravnom smislu nije bio irski rezident, unatoč tome što je riječ o subjektu osnovanom prema irskom pravu. Naime, prema irskom poreznom pravu pojam rezidenta ne obuhvaća ona trgovačka društva koja u Irskoj obavljaju "komercijalnu aktivnost" (engl. trading activity), ali se mjesto njihove "središnje uprave i nadzora poslovanja" nalaze izvan Irske. ${ }^{45}$

$S$ druge strane, AOI nije niti rezident SAD-a, s obzirom na to da američko porezno pravo polazi od tzv. formalističkog pristupa te rezidentnim trgovačkim društvima smatra samo društva osnovana prema pravu SAD-a. Interakcija unutarnjih poreznih pravila navedenih dviju država za posljedicu ima klasičan slučaj "dvostruke ne-rezidentnosti”: AOI nije fiskalni rezident niti jedne države. ${ }^{46}$ Posljedično, ni Irska ni SAD nemaju pravo oporezovati ukupnu "svjetsku dobit" ovog društva, nego isključivo onaj dio dobiti čiji se "izvor" nalazi na njihovu teritoriju. Pritom valja dodati da je AOI u razdoblju od 2007. do 2012. godine morao plaćati porez na dobit sukladno načelu izvora isključivo jednoj državi - Irskoj. Istodobno, dobit AOI-a iznosila je oko 30\% ukupne svjetske dobiti Apple grupe, s time da je pretežito riječ o dividendama isplaćenim od strane društava-kćeri. ${ }^{47}$

AOE (prije: Apple Computer Ltd.) je irsko društvo u 100\%-tnom vlasništvu AOI-ja. Također riječ je o društvu koje nije porezni rezident niti jedne države, sukladno gore opisanoj interakciji između američkog i irskog poreznog prava. Međutim, za razliku od svojeg društva-majke, AOE u Irskoj obavlja značajne ekonomske aktivnosti. Oko 400 zaposlenika ovog društva obavlja poslove vezane uz pružanje različitih vrsta usluga drugim članovima Apple grupe (npr. usluge obračuna plaća, zajedničke nabave, ljudskih potencijala i korisničkog servisa), ali i uz proizvodnju određenih računala i računalnih komponenti (npr. iMac računala). Sukladno tome, Irska ima pravo oporezivati onaj dio dobiti AOE-a koji se može pripisati ovim aktivnostima, tj. irskoj stalnoj poslovnoj jedinici (dalje: SPJ-u) AOE-a. ${ }^{48}$

43 Vidjeti The Permanent Subcommittee On Investigations (2013), Offshore Profit Shifting and the U.S. Tax Code - Part 2 (Apple Inc.), dostupno na: http://www.hsgac.senate.gov/subcommittees/investigations/hearings/offshore-profit-shifting-and-the-us-taxcode-part-2. Pristupljeno 12. lipnja 2017., str. 18.

Za ovaj pojam vidi: Arbutina, Ott, op. cit., u bilj. 4, str. 303.

Vidjeti Odluku EK-a, para. 48.-52.

Za pojašnjenje različitih pristupa određenju porezne rezidentnosti trgovačkih društava v. Gadžo, S., Međunarodno porezno planiranje multinacionalnih korporacija s posebnim osvrtom na ulogu nematerijalne imovine (II.), Pravo i porezi, br. 4/2016., str. 16.-17.

Vidjeti The Permanent Subcommittee On Investigations, op. cit., u bilj. 43, str. 22.-23.

Općenito o pojmu stalne poslovne jedinice u međunarodnom poreznom pravu v. Gadžo, op. cit., u bilj. 46, str. 17.-18. Općenito o mehanici pripisivanja dobiti SPJ-ima v. Čičin-Šain, N., Novi pristup u određenju dobiti stalne poslovne jedinice - pristup OECD-a te implikacije za hrvatsko porezno pravo, Zbornik Pravnog fakulteta Sveučilišta u Rijeci, vol. 37, br. 3/2016., str. 1231.-1249. 
ASI je ključni subjekt u Appleovoj globalnoj poreznoj strategiji. Također je riječ o trgovačkom društvu osnovanom prema irskom pravu koje nije porezni rezident niti jedne države (vidi supra). ASI je u 100\%-tnom vlasništvu AOE-a, a njegove su temeljne funkcije sljedeće: 1) nabava gotovih Apple proizvoda (npr. iPhonei, iPadi i sl.) od proizvođača izvan grupacije, uglavnom kineskih poduzeća i 2) daljnja prodaja istih proizvoda društvima-distributerima unutar Apple grupe koji opskrbljuju lokalna tržišta. Vrijedi naglasiti da velika većina proizvoda ni u jednom trenutku u fizičkom obliku ne prolazi kroz Irsku, nego se izravno iz skladišta proizvođača dostavlja krajnjim potrošačima. Ove je aktivnosti do 2012. godine ASI obavljao bez ijednog zaposlenika (sic!), nakon čega, zbog restrukturiranja grupe, zapošljava 250 osoba prethodno zaposlenih u matičnom društvu (AOE-u). Dobit ASI-ja kontinuirano je rasla kroz godine, a ponajprije proizlazi iz razlike između nabavne cijene proizvoda i prodajne cijene naplaćene povezanim društvima. Tako u 2011. godini ukupna dobit ASI-ja iznosi 22 mlrd. USD. Međutim, u svjetlu gore navedene činjenice da društvo nije irski porezni rezident, od toga je u Irskoj oporezivo tek $0,22 \%$ (cca 50 mil. USD) jer je to onaj dio dobiti koji se može pripisati irskoj podružnici (tj. stalnoj poslovnoj jedinici) ASI-ja i podliježe oporezivanju irskim porezom na dobitak po stopi od 12,5\%. Ostatak od više od 20 mlrd. USD dobiti ostvarene samo u toj godini ostaje potpuno neoporeziv, čak i u kasnijem trenutku, kad se u obliku dividende isplati matičnim društvima (AOE i AOI), s obzirom na to da su ovi subjekti također "dvostruki nerezidenti”.

Slika 1: pojednostavnjeni prikaz organizacijske strukture Apple grupe

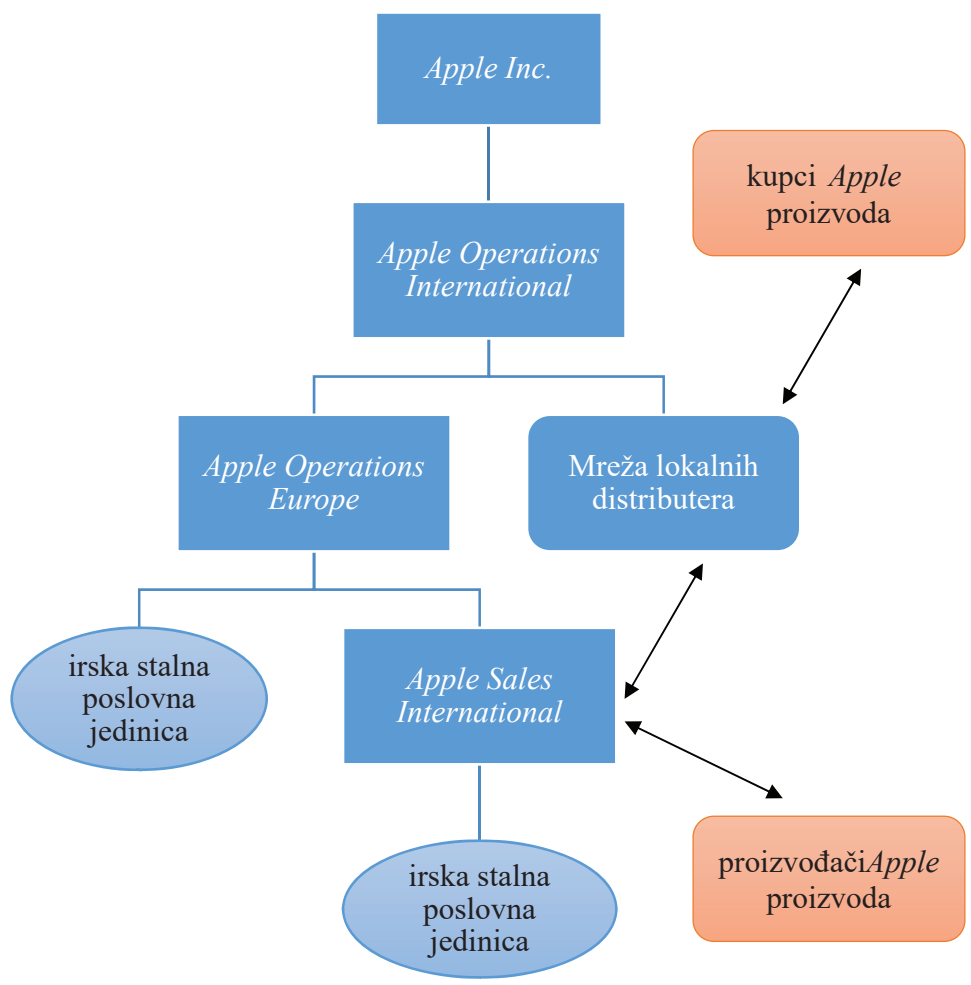




\subsection{ULOGA NEMATERIJALNE IMOVINE I UGOVORA O PODJELI TROŠKOVA ISTRAŽIVANJA I RAZVOJA}

Za uspjeh porezne strategije velikih MNK-a iz informacijsko-tehnološkog sektora, poput Applea, od presudne je važnosti porezno učinkovito upravljanje nematerijalnom imovinom (npr. autorska prava, žigovi, patenti, know-how i dr.). Naime, upravo su resursi nematerijalne imovine glavni generator dodane vrijednosti ovih subjekata u sklopu njihovih globalnih vrijednosnih lanaca (engl. global value chain). ${ }^{49}$ Primjerice, najveći dio cijene koju plaćaju krajnji kupci Appleovih proizvoda i usluga otpada na vrijednost patenata, žigova, dizajna i/ili branda korištenih pri proizvodnji, oglašavanju i/ili distribuciji proizvoda/usluga. Upravo stoga je za potrebe oporezivanja dobitka odlučujuće identificirati subjekte (trgovačka društva i/ili SPJ-e) unutar grupacije kojima, polazeći od načela neovisnosti i pravila o transfernim cijenama, pripada udio u ukupnoj dobiti povezan s iskorištavanjem nematerijalne imovine. Ako se uzme u obzir supra izložena organizacijska struktura grupe, uočava se da bi za Apple grupu bilo u poreznom smislu najpovoljnije najveći dio ukupne dobiti alocirati "irskim" društvima (AOI, AOE i ASI) koji nisu porezni rezidenti niti jedne države.

U građanskopravnom smislu nositelj svih prava intelektualnog vlasništva korištenih za Appleove poslovne djelatnosti je američko "krovno društvo", Apple Inc. Međutim, radi pripisivanja dijela dobiti od tih i drugih oblika nematerijalne imovine irskim zavisnim društvima, Apple Inc. s AOE-om i ASI-jem sklapa tzv. ugovor o podjeli troškova (engl. cost-sharing agreement). ${ }^{50} \mathrm{Na}$ temelju ovog ugovora stranke pristaju na podjelu troškova istraživanja i razvoja (IR) određenih oblika nematerijalne imovine koje će u kasnijem trenutku zajednički iskorištavati. Porezni cilj ugovora je sljedeći: svakoj se stranci, sukladno udjelu koji snosi u ukupnim troškovima IR aktivnosti, može pripisati udio u ukupnoj dobiti koja će poslije biti ostvarena iskorištavanjem nematerijalne imovine u poslovnim procesima. U konkretnom se slučaju na taj način izbjegava potreba za plaćanjem unutargrupnih autorskih naknadi ili licencija (engl. royalties), koje bi umanjivale poreznu osnovicu irskih supsidijarija te ujedno povećavale poreznu osnovicu američkog društva. Glavna porezno-pravna posljedica sklapanja ugovora o podjeli troškova jest da se ASI i AOI smatraju "ekonomskim vlasnicima" nematerijalne imovine koja se koristi u svim Appleovim proizvodima na području izvan Sjeverne i Južne Amerike. ${ }^{51}$ Posljedično se upravo ovim subjektima može pripisati najveći dio dobiti od prodaje ostvarene na preostalom dijelu globalnog tržišta.

Uporabom ove klasične tehnike međunarodnog poreznog planiranja Apple grupa zapravo na umjetan način povećava dobit irskih društava te tako umanjuje ukupno porezno opterećenje grupe. Tri argumenta ukazuju da je posrijedi struktura bez kakvog drugog ekonomskog opravdanja. Prvo, aktivnosti istraživanja i razvoja, koje rezultiraju stvaranjem nematerijalne imovine, gotovo se u potpunosti poduzimaju na području SAD-a. ${ }^{52}$ Štoviše, evidentno je da irska društva ASI i AOE, kao stranke ugovora o podjeli troškova, nemaju ni približan broj adekvatno osposobljenih zaposlenika koji bi mogli značajnije pridonijeti IR aktivnostima grupe. Dakle, jedino

Vidjeti Gadžo, op. cit., u bilj. 9, str. 744.-745.

Općenito o značenju ovih ugovora za porezno planiranje v.: ibid., str. 755.

Vidjeti Ting, A., iTax: Apple's International Tax Structure and the Double Non-Taxation Issue, British Tax Review, br. 1, $2014 .$, str. 44.

Vidjeti The Permanent Subcommittee On Investigations, op. cit., u bilj. 43, str. 28. 
čime navedena društva pridonose IR aktivnostima jest plaćanje troškova u okviru unutargrupnog pravnog odnosa. Iz analize omjera troškova IR-a koje je tijekom trajanja ugovora snosila svaka stranka ugovora i njihove bruto dobiti, vidljivo je da ASI i AOE imaju mnogo više koristi od ugovora nego njihovo društvo-majka, Apple Inc. ${ }^{53}$ Drugo, ne postoji valjani ratio da se "ekonomsko vlasništvo" nad nematerijalnom imovinom dodijeli baš irskim društvima, umjesto drugim subjektima unutar grupacije, osnovanim u drugim državama. To pogotovo kad se uzme u obzir da do 2012. godine ASI nije imao nijednog zaposlenika, a članovi njegove uprave bili su zapravo zaposlenici Apple Inc.-a, čiji se sastanci održavaju u SAD-u (vidi supra, poglavlje 2.1.). Treće, analiza svih činjenica slučaja, a napose načina donošenja odluka unutar grupe, ukazuje da svi subjekti unutar grupe postupaju u skladu s jedinstvenom globalnom strategijom te se u biti doista može govoriti o jednom jedinstvenom poduzeću, bez obzira na zasebnu pravnu egzistenciju njegovih sastavnica. Stoga i predmetni ugovor o podjeli troškova nema nikakav stvarni ekonomski učinak, osim porezno-računovodstvenog "prelijevanja" dobiti unutar grupe. ${ }^{54}$

Jedan od najvećih rizika za uspjeh opisane porezne strategije jest mogućnost da američke porezne vlasti, primjenom tzv. pravila o kontroliranim inozemnim korporacijama (engl. controlled foreign corporations rules; dalje: CFC pravila) ${ }^{55}$, naknadno povećaju poreznu osnovicu krovnog društva, Apple Inc.-a. Osiguranje od ovog poreznog rizika relativno je jednostavno, u svjetlu specifičnog instituta američkog poreznog prava, tzv. check the box pravila. Ovaj institut omogućuje američkim MNK-ima da slobodno odaberu hoće li trgovačka društva unutar njihove grupacije, za potrebe američkoga poreznog prava, zadržati porezno-pravni subjektivitet ili će se smatrati "fiskalno transparentnim" entitetima. ${ }^{56}$ U konkretnom slučaju od svih Appleovih inozemnih zavisnih društava jedino AOI (irsko holding društvo, vidi supra, poglavlje 2.1.) zadržava porezno-pravni subjektivitet te se njemu pripisuju prihodi i rashodi od svih aktivnosti zavisnih društava, poput ASI-ja. Na ovaj način grupacija se štiti od primjene američkih CFC pravila. Naime, AOI iz perspektive američkog poreznog prava postaje društvo koje obavlja "aktivnu" poslovnu aktivnost, čime se automatski isključuje primjena CFC pravila pri oporezivanju njegove dobiti.

Zahvaljujući opisanom "poreznom inženjeringu” efektivno porezno opterećenje dobitka koji je Apple grupa ostvarila od prodaje na ne-američkom segmentu globalnog tržišta gotovo je nevjerojatno nisko, napose kad se u obzir uzmu nominalne (zakonske) stope poreza u pojedinim državama u kojima Apple posluje. Tako je, prema izračunu Europske komisije, efektivno porezno opterećenje ASI-ja, subjekta kojemu se pripisuje najveći dio dobitka ostvarenog izvan američkog segmenta tržišta (vidi supra), iznosilo 0,05\% u 2011. godini te 0,005\% u 2014. godini. ${ }^{57}$ Promatrano u nominalnim vrijednostima, gotovo $16 \mathrm{mlrd}$. EUR od ukupne dobiti ASI-ja ostvarene 2011. godine ostalo je potpuno neoporezivo. To je, kako je gore detaljnije izloženo, u najvećem dijelu posljedica: 1) činjenice da je riječ o društvu koje nije fiskalni rezident niti jedne države te 2) sklopljenog ugovora o podjeli troškova istraživanja i razvoja s matičnim društvom, Apple Inc.-om.

53 Ibid., str. 29.

54 Vidjeti The Permanent Subcommittee On Investigations, op. cit., u bilj. 43, str. 30.-31.

55 O ovim pravilima v. detaljnije: Gadžo, op. cit., u bilj. 9, str. 751.

56 Općenito o komparativnom aspektima regulacije fiskalno transparentnih subjekata v. Easson, A., Thurony, V., Fiscal Transparency, u: Thurony, V., Tax law design and drafting (vol. 2), International Monetary Fund, Washington, 1998., str. 925.-968.

57 Vidjeti European Commission (2016), State aid: Ireland gave illegal tax benefits to Apple worth up to $€ 13$ billion, dostupno na: http://europa.eu/rapid/press-release-IP-16-2923-en.htm. Pristupljeno 11. listopada 2017. 


\section{ODLUKA EUROPSKE KOMISIJE: POSTUPCI IRSKIH POREZNIH TIJELA KAO ZABRANJENA DRŽAVNA POTPORA}

Supra izložena porezna strategija Applea prijeporna je iz perspektive prava državnih potpora Europske unije stoga što su irske porezne vlasti u čak dva navrata donijele obvezujuće porezno mišljenje, ${ }^{58}$ kojim su u biti pristale na ciljani rezultat porezne strategije Apple grupe.

Postupci irskih poreznih vlasti sežu u 1991. godinu, kada im se Apple obraća s prijedlogom metode utvrđenja onog dijela dobiti grupacije koji se može pripisati irskim podružnicama društava: AOE-u i ASI-ju. Valja podsjetiti da su posrijedi društva koja nisu fiskalni rezidenti Irske te stoga, sukladno relevantnim pravilima međunarodnog poreznog prava, Irska ima pravo oporezovati isključivo dobit ostvarenu preko SPJ-a smještenih na njezinu teritoriju. Oba društva u Irskoj posluju preko podružnice, što je jedan od tipičnih oblika SPJ-a. Vidljivo je da je zapravo riječ o klasičnom slučaju primjene pravila o transfernim cijenama, i to na odnos između društava AOE-a i ASI-ja i njihovih irskih SPJ-a.

U obvezujućem mišljenju izdanom 1991. godine irska je porezna administracija, nakon pregovora s Appleom, potvrdila da će se dobit irskih SPJ-a u idućem razdoblju izračunavati kao unaprijed određeni postotak ukupnih operativnih troškova koji im se mogu pripisati. ${ }^{59}$ Godine 2007. izdano je novo obvezujuće mišljenje, kojim se način izračuna dobitka oporezivog u Irskoj tek blago modificira. Na ovaj su način irske porezne vlasti zapravo u dva navrata izričito pristale da tek manji dio ukupne dobiti društava AOE-a i ASI-ja bude oporeziv u Irskoj. Naime, najveći udio u dobiti ovih društava vezan je za korištenje i upravljanje nematerijalnom imovinom (vidi: supra, poglavlje 2.2.), a taj dio dobiti nije pripisan njihovim irskim SPJ-ima.

\subsection{POSTUPAK I ODLUKA EUROPSKE KOMISIJE}

U lipnju 2013. godine Europska je komisija pokrenula opsežnu istragu obvezujućih poreznih mišljenja izdanih u različitim državama članicama EU-a s aspekta prava državnih potpora. Istraga je intenzivirana krajem 2014. godine u svjetlu afere Luxembourg Leaks, na temelju koje je šira javnost upoznata s praksom luksemburških poreznih vlasti u davanju povlaštenog poreznog tretmana najvećim multinacionalnim kompanijama. ${ }^{60}$ Istraga "slučaja Apple" pokrenuta je još 2013., kada je Europska komisija službenim putem od nadležnih tijela Republike Irske zatražila dostavu temeljnih informacija, a napose samih obvezujućih mišljenja donesenih 1991. i 2007. godine. Nakon pribavljanja dodatne dokumentacije i očitovanja irskih poreznih tijela, EK 30. kolovoza 2016. donosi tzv. negativnu odluku, kojom utvrđuje da je Irska, izdavanjem navedenih obvezujućih poreznih mišljenja, Appleu dodijelila zabranjenu državnu potporu. Nadalje, Irskoj je naložen tzv. povrat nezakonite potpore (engl. recovery of illegal state aid), što znači da mora od Applea tražiti povrat neplaćenog poreza, uz pripadajuće kamate, u razdoblju od 2003. do 2014. godine. Iako u odluci EK-a ovaj iznos nije izračunat - to je obveza

\footnotetext{
58 O ovom institutu u kontekstu prava državnih potpora EU-a v. detaljnije supra, poglavlje 2.1.

59 Vidjeti detaljnije: Odluka EK-a, para. 59.-68. 
Irske kao davateljice potpore - prema prvim je procjenama, koje polaze od glavnih činjeničnih nalaza Komisije, riječ o 13 mlrd. EUR neplaćenog poreza, od čega 99,99\% otpada na neutemeljenu alokaciju dobiti između društva ASI i njegova irskog SPJ-a ${ }^{61}$ Vrijedi naglasiti kako u formalno-pravnom smislu nije riječ o novčanoj kazni izrečenoj Appleu, nego o povratu državne potpore koju je ovom poduzeću neopravdano dodijelila država članica. Naime, cilj instituta povrata potpore ponovno je uspostavljanje jednakosti između tržišnih aktera (poduzetnika) na unutarnjem tržištu EU-a. ${ }^{62}$

\subsection{ARGUMENTACIJA EUROPSKE KOMISIJE}

Istraga EK-a u slučaju Apple zapravo je bila usmjerena na sljedeće materijalnopravno pitanje: je li Irska, izdavanjem obvezujućih mišljenja 1991. i 2007. godine, Apple grupi dala zabranjenu državnu potporu, s obzirom na mehanizam pripisivanja dobiti irskim stalnim poslovnim jedinicama društava ASI i AOE utjelovljen u predmetnim aktima? Odgovor na to pitanje podrazumijeva detaljnu analizu slučaja s aspekta načela neovisnosti, s obzirom na to da ono ima ključnu ulogu i pri alokaciji dobiti između trgovačkog društva - rezidenta jedne države i njegova SPJ-a smještenog u drugoj državi.

U obrazloženju nalaza da je riječ o zabranjenoj državnoj potpori EK polazi od analize ispunjenja definicijskih elemenata državne potpore (supra, poglavlje 2.). Tako je prvo utvrđeno da se promatrana mjera može pripisati Irskoj te da, zbog toga što dovodi do umanjenja poreznih prihoda, predstavlja financijsko opterećenje za ovu državu članicu. ${ }^{63}$ Drugo, EK smatra nespornim da mjera u pitanju utječe na trgovinu između država članica EU-a, s obzirom na tržišta na kojima Apple djeluje. Također, uvjet "narušavanja tržišnog natjecanja” smatra se ispunjenim jer Apple dobiva povoljniji položaj na tržištu u odnosu na druge poduzetnike, u onoj mjeri u kojoj predmetni akti irskih poreznih vlasti dovode do umanjenja poreznog opterećenja Apple grupe u odnosu na ono što je predviđeno općim pravilima irskog poreznog prava. ${ }^{64}$ Upravo se u tom umanjenju poreznog opterećenja, prema stajalištu EK-a, ogleda i ispunjenje trećeg uvjeta, dodjeljivanja ekonomske prednosti određenom poduzetniku. ${ }^{65}$

Dakako, u obrazloženju svoje odluke Europska komisija je uvjerljivo najviše prostora posvetila pitanju je li promatrana mjera selektivna, što je presudni uvjet za njezinu kvalifikaciju zabranjenom državnom potporom. Sukladno ustaljenoj praksi poduzimanja testa selektivnosti (supra, poglavlje 2.), Komisija je najprije odredila referentni porezno-pravni okvir. Prema mišljenju EK-a, referentni okvir u predmetnom slučaju čini normativni okvir oporezivanja dobitka u Irskoj, odnosno skup pravila irskog prava poreza na dobit koja se načelno primjenjuju na sve obveznike ovog poreznog oblika (inter alia, pravila o predmetu oporezivanja, poreznoj

\footnotetext{
61 Vidjeti https://assets.kpmg.com/content/dam/kpmgxx/pdf/2016/08/etf300-state-aid-decision-in-the-apple-case. pdf. Pristupljeno 18. lipnja 2017.

62 Vidjeti Micheau, op. cit., u bilj. 21, str. 207.-208.

63 Vidjeti Odluka EK-a, para. 221.

64 Ibid., para. 222.

65 Ibid., para. 223. U tom smislu EK očito smatra da je riječ o prvom od tri supra izložena (poglavlje 2.) načina dodjeljivanja državne potpore preko poreznog sustava, tj. smanjenju porezne osnovice.
} 
stopi, poreznim oslobođenjima i dr.). ${ }^{66} \mathrm{~S}$ obzirom na to da je temeljni cilj korpusa ovih pravila oporezovati dobit svih subjekata u odnosu na koje Irska može uspostaviti poreznu jurisdikciju, ${ }^{67} \mathrm{u}$ činjenično i pravno usporedivoj situaciji nalaze se svi porezni obveznici, bez obzira na to je li riječ o irskim rezidentima ili ne, te jesu li isti dio kakve složenije organizacijske strukture, poput MNK-a. ${ }^{68} \mathrm{U}$ tom smislu Komisija nije prihvatila stavove Irske i Applea, istaknute tijekom postupka, da se referentni sustav mora ograničiti ili na samo ona pravila irskog poreznog prava koja se primjenjuju na trgovačka društva - nerezidente ili na pravila koja uređuju oporezivanje unutargrupnih transakcija. ${ }^{69}$

Drugi se korak testa selektivnosti zapravo svodi na pitanje mogu li se predmetni akti irskih poreznih vlasti označiti mjerama kojima se odstupa od referentnog porezno-pravnog okvira te koje uzrokuju nejednaki tretman usporedivih subjekata. Pritom vrijedi naglasiti stav EK-a da je ovo pitanje identično s pitanjem ispunjenja jednog od četiri kumulativne pretpostavke za utvrđenje postojanja zabranjene državne potpore - uvjeta dodjeljivanja ekonomske prednosti određenom poduzetniku. Naime, povoljniji porezni tretman koji uživa određeni poduzetnik u odnosu na druge usporedive poduzetnike označava ujedno i odstupanje od referentnog okvira u smislu provođenja testa selektivnosti, kao i ispunjenje općeg uvjeta ostvarenja ekonomske prednosti. $^{70}$

EK zastupa stav da davanje odgovora na ovo pitanje zapravo zahtijeva analizu predmetnih akata kroz prizmu načela neovisnosti. Prvotno vrijedi primijetiti kako načelo neovisnosti, detaljnije razrađeno pravilima o transfernim cijenama, ima status općeprihvaćenog mehanizma alokacije prihoda i rashoda između povezanih društava i njihovih stalnih poslovnih jedinica, tj. različitih sastavnica MNK-a. ${ }^{71}$ Polazeći od ciljnog tumačenja čl. 107., st. 1 . UFEU-a, a napose odluke Suda EU-a u tzv. predmetu Forum $187,{ }^{72}$ EK smatra da porezna tijela država članica moraju slijediti ovo načelo pri donošenju tzv. APA sporazuma ili sličnih akata kojima se utvrđuje raspodjela prihoda i rashoda unutar MNK-a. ${ }^{73}$ Naime, ako se prihvati supra izloženi argument da referentni porezno-pravni okvir čine opći sustav oporezivanja dobitka u jednoj državi članici, načelo neovisnosti nameće se kao nužni standard za ostvarenje jednakog tretmana između onih poreznih obveznika koji prihode/rashode ostvaruju isključivo tzv. nekontroliranim transakcijama na otvorenom tržištu i onih poreznih obveznika koji barem dio prihoda/rashoda ostvaruju tzv. kontroliranim transakcijama, tj. u okviru trgovačkih i/ili financijskih odnosa s drugim sastavnicama istog MNK-a. ${ }^{74}$ Upravo stoga EK smatra da načelo neovisnosti čini upo-

66 Vidjeti Odluku EK-a, para. 228.

67 Općenito o pojmu porezne jurisdikcije v. Arbutina, H., Određenje osobnog i predmetnog obuhvata porezne obveze pri oporezivanju dohotka i dobiti, Zbornik Pravnog fakulteta u Zagrebu, vol. 47, br. 1-2, 1997., str. 160.

Vidjeti Odluku EK-a, para. 229.-230.

Zanimljivo, Europska komisija je provela i "alternativni test selektivnosti", polazeći od užeg referentnog sustava, sukladno navedenom stajalištu Irske i Applea. Vidjeti Odluku EK-a, para. 369.-403.

Vidjeti Odluku EK-a, para 224. Odluke. Usp. Schön, W., Tax Legislation and the Notion of Fiscal Aid: A Review of 5 Years of European Jurisprudence, u: Richelle, I. et al. (ur.), State Aid Law and Business Taxation, Springer, Berlin, 2016., str. 7.-9.; Lovdahl Gormsen, op. cit., u bilj. 8, str. 374.-375.

72 Vidjeti supra, bilj. 38.

73 O pojmu APA sporazuma v. supra, bilj. 34. 
rište u provođenju testa selektivnosti, bez obzira na činjenicu da ono nije izričito propisano irskim poreznim pravom. ${ }^{75}$ Što se tiče uloge OECD-ovih Smjernica o transfernim cijenama, neobvezujućeg dokumenta koji utjelovljuje najbolje prakse u primjeni pravila o transfernim cijenama, stav je EK-a da se ne mogu izravno primijeniti u procjeni kakve mjere ili postupanja s aspekta prava državnih potpora, ali odstupanje od njihovih preporuka predstavlja indiciju da je riječ o zabranjenoj državnoj potpori u smislu čl. 107, st. 1. UFEU-a. ${ }^{76}$

U tom smislu EK smatra da predmetni akti irskih poreznih vlasti nisu usklađeni s načelom neovisnosti te se stoga njima Appleu daje selektivna državna potpora. Ovaj zaključak EK temelji na dva nalaza: ${ }^{77}$

(i) predmetni akti polaze od neosnovane pretpostavke da autorske naknade koje ubiru društva ASI i AOE nemaju izvor u Irskoj te ih se ne može pripisati irskim SPJ-ima ovih društava;

(ii) podredno i neovisno od prethodnog nalaza, metodologija alokacije prihoda i rashoda u predmetnim aktima nije prihvatljiva u svjetlu načela neovisnosti.

Što se tiče nalaza pod ad. (i), stav je irskih poreznih vlasti, utjelovljen i u predmetnim aktima, da se Appleovim SPJ-ima smještenim u Irskoj ne mogu pripisati prihodi od unutargrupnih autorskih naknada. Tijekom postupka ovaj stav Republika Irska potkrepljuje činjenicom da SPJ-i obavljaju operativne i logističke funkcije rutinske naravi, a ključne odluke vezane za upravljanje nematerijalnom imovinom donose se izvan Irske, na sastancima uprave društava AOE i ASI. ${ }^{78}$ Stoga irske vlasti drže da se "ekonomsko vlasništvo" nad pojedinim oblicima Appleove nematerijalne imovine ne može dodijeliti predmetnim SPJ-ima.

S druge strane, Europska komisija početno je naglasila da su irska porezna tijela, u postupku izdavanja predmetnih akata, imala dužnost provođenja tzv. funkcionalne analize. ${ }^{79}$ Prethodno opisani stav irskih poreznih vlasti bio bi prihvatljiv jedino ako bi takva analiza uzimajući u obzir funkcije, imovinu i rizike pojedinih dijelova društava ASI-ja i AOE - ukazala da unutargrupne autorske naknade ne mogu biti pripisane irskim SPJ-ima. ${ }^{80} \mathrm{U}$ tom smislu EK posebno upozorava na činjenicu da mjesto uprave (engl. head office) oba promatrana društva (ASI-ja i AOE-a) postoji samo "na papiru", s obzirom na to da ista nemaju ni zaposlenika ni materijalne imovine, izvan vlastitih SPJ-a smještenih u Irskoj. ${ }^{81}$ Također, u svjetlu dostupne dokumentacije (npr. zapisnici sastanaka upravnih odbora), EK odbacuje tvrdnje irskih poreznih vlasti da su se ključne poslovne odluke vezane uz upravljanje nematerijalnom imovinom donosile isključivo na razini uprave promatranih društava. ${ }^{82}$ Štoviše, aktivno upravljanje ne-

75 Vidjeti Odluku EK-a, para. 257. Ovakav stav EK-a potvrđen je i u najnovijem dokumentu u kojem se objašnjava pojam državne potpore u smislu čl. 107. UFEU-a. Vidjeti Europska komisija, op. cit., u bilj. 26, para. 172. O prijeporima vezanim za pravni status načela neovisnosti v. infra, poglavlje 5 .

76 Vidjeti Odluku EK-a, para. 255.

77 Vidjeti Odluku EK-a, para. 258.-261.

78 Vidjeti Odluku EK-a, para 195. Za pojašnjenje funkcija pojedinih subjekata unutar Apple grupe v. supra, poglavlje 3.1.

79 Za značaj funkcionalne analize u primjeni načela neovisnosti v. Gadžo, op. cit., u bilj. 9, str. 753.-754.

80 Vidjeti Odluku EK-a, para. 280.

81 Vidjeti Odluku EK-a, para. 281. 
materijalnom imovinom Applea nije se ni moglo obavljati isključivo na sastancima članove uprave, bez angažmana drugih zaposlenika. Stoga se mjestu uprave ne mogu pripisati, za potrebe primjene načela neovisnosti, ključni rizici vezani za nematerijalnu imovinu u pitanju. ${ }^{83}$ S druge strane, EK smatra da irski SPJ-i obavljaju određene funkcije važne za upravljanje nematerijalnom imovinom i njezin razvoj, poput marketinških aktivnosti, razvoja Apple branda, prikupljanja i obrade podataka, komunikacije s korisnicima i $\mathrm{dr} .{ }^{84} \mathrm{~S}$ obzirom na navedeno, EK zaključuje da alokacija unutargrupnih autorskih naknada odobrena u predmetnim aktima irskih poreznih vlasti nije u skladu s načelom neovisnosti. To za posljedicu ima znatno umanjenje onog dijela dobiti društava ASI-ja i AOE-a koji je oporeziv u Irskoj, što predstavlja davanje selektivne ekonomske prednosti. ${ }^{85}$

Kao što je već naznačeno supra pod ad. (ii), Europska je komisija do istog zaključka došla i s pomoću alternativnog pravca rasuđivanja. Naime, čak i ako se prihvati stav irskih poreznih vlasti da se unutargrupne autorske naknade ne mogu alocirati irskim SPJ-ima društava ASIja i AOE-a, metodologija alokacije prihoda i rashoda utjelovljena u predmetnim aktima nije usklađena sa zahtjevima načela neovisnosti. Ponajprije valja primijetiti da je način alokacije prihoda i rashoda u predmetnim aktima veoma sličan tzv. metodi transakcijske neto-marže, jednoj od metoda transfernih cijena preporučenih u OECD-ovim Smjernicama. Ova se metoda zasniva na određenju relativnog odnosa između neto-dobitka kojeg jedan subjekt) unutar MNK-a (tzv. testirana strana) ostvari iz kontroliranih transakcija s jedne strane i nekog ekonomskog indikatora (npr. ukupni troškovi, prihodi od prodaje, imovina) s druge. Dobivena se veličina potom uspoređuje s onom koja se u sličnim okolnostima ostvaruje u nekontroliranim transakcijama. ${ }^{86} \mathrm{U}$ konkretnom slučaju irska su porezna tijela razmatrala aktivnosti irskih SPJ-a ASI-ja i AOE-a kao testiranih strana, polazeći od pretpostavke da ovi subjekti obavljaju manje složene funkcije u odnosu na mjesta uprave istih društava. Kao relevantni ekonomski indikatori odabrani su operativni troškovi SPJ-a, s time da je u poreznom mišljenju iz 2007. godine u obzir uzet i određeni postotak prometa ostvaren u SPJ-u društva AOE-a. ${ }^{87}$

EK osporava ispravnost metodologije primijenjene pri izdavanju predmetnih akata. Prvo, neutemeljena je pretpostavka da irski SPJ-i društava ASI i AOE obavljaju manje složene funkcije u odnosu na ostatak društva (tj. upravu, vidi supra) te je stoga i upitan odabir SPJ-a kao "testiranih strana" u primjeni navedene metode transfernih cijena. ${ }^{88}$ Drugo, EK detaljno obrazlaže zašto su ekonomski indikatori od kojih polazi analiza u predmetnim aktima neprikladni za dosezanje rezultata alokacije usklađenog s načelom neovisnosti. ${ }^{89}$ Prema mišljenju Komisije, pri alokaciji dobiti SPJ-u društva ASI irska su porezna tijela morala uzeti u obzir prihode od prodaje ostvarene preko ovog subjekta, a ne tek njegove operativne troškove. Kad je riječ o SPJ-u društva ASI, ukupni troškovi, umjesto operativnih troškova, bili bi podobniji pokazatelj. U svakom slučaju, metodološki odabir irskih poreznih tijela rezultirao je umanjenjem opore-

\footnotetext{
83 Vidjeti Odluku EK-a, para. 288.-292.

84 Vidjeti Odluku EK-a, para. 295.-304.

85 Vidjeti Odluka EK-a, para. 320.

86 Detaljnije v. OECD, op. cit., u bilj. 34, str. 117.-132.

87 Detaljnije v. Odluku EK-a, para. 59.-62.

88 Vidjeti Odluku EK-a, para. 328.-333. 
zive dobiti irskih SPJ-a. Treće, zaključak je EK-a da je neto marža irskih SPJ-a u predmetnim aktima podcijenjena te u svakom slučaju nije utemeljena na objektivnim analizama, nego je rezultat pregovora između Applea i irskih vlasti..$^{90}$

S obzirom na sve gore navedeno, EK donosi zaključak da predmetni akti irskih poreznih vlasti dovode do umanjenja poreznog opterećenja društava ASI-ja i AOE-a, u usporedbi s drugim subjektima čija se dobit oporezuje u Irskoj, a čiji prihodi i rashodi odražavaju tržišne odnose između nepovezanih osoba. Navedeno se stoga ima smatrati selektivnom državnom potporom dodijeljenom društvima ASI-ju i AOE-u. U prilog ovom zaključku EK upućuje i na dvije dodatne okolnosti. Prvo, dokumentacija na temelju koje su irske porezne vlasti donijele predmetne akte nije sadržavala studiju (elaborat) o transfernim cijenama, što je inače temeljna pretpostavka za izdavanje APA sporazuma. Drugo, prvo porezno mišljenje, izdano 1991. godine, bilo je na snazi petnaest godina, što je, komparativno gledano, neuobičajeno dugo razdoblje te izaziva dodatne sumnje $\mathrm{u}$ ispravnost predviđenih alokacijskih ishoda. ${ }^{91}$

Kako je navedeno supra, treći korak u provedbi testa selektivnosti svodi se na pitanje opravdanja promatrane mjere $\mathrm{i}$ to u svjetlu prirode ili opće sheme referentnog porezno-pravnog okvira. Komisija se ukratko osvrnula i na ovo pitanje, bez obzira na to što irske vlasti tijekom postupka uopće nisu istaknule moguća opravdanja. S druge strane, Apple grupa je istaknula tri argumenta koja ukazuju na opravdanost mjere u pitanju. Prvo, Apple smatra da su predmetna porezna mišljenja rezultat diskrecijskog postupanja irskih poreznih tijela, što je dio opće sheme oporezivanja dobiti prema irskom pravu. EK odbacuje ovaj argument naglašavajući kako pravo poreznih tijela na diskrecijsko postupanje u rješavanju poreznih predmeta ne može samo po sebi opravdati nejednaki tretman poreznih obveznika koji su, u činjeničnom i pravnom smislu, usporedivi, napose u izostanku ikakvih objektivnih kriterija. ${ }^{92}$ Drugo, Europska komisija nije prihvatila mišljenje Applea kako se predmetni akti temelje na relevantnim načelima irskog sustava poreza na dobit, s obzirom na manjak objektivnih kriterija od kojih irska porezna tijela polaze pri odlučivanju o alokaciji prihoda i rashoda. ${ }^{93}$ Konačno, Europska komisija odbacila je i tvrdnju Applea da su predmetni akti doprinijeli učinkovitosti irskog poreznog sustava, s obzirom na to da to samo po sebi ne može opravdati selektivnu poreznu mjeru. ${ }^{94}$

\section{KRITIKE ODLUKE EUROPSKE KOMISIJE: QUO VADIS?}

Negativna odluka EK-a u slučaju Apple, utemeljena na supra sažetim pravnim i činjeničnim nalazima, izazvala je mnogovrsne prijepore, i unutar znanstvene i stručne javnosti, ali i s najviših političkih razina. To dakako ne čudi ako se ima u vidu globalni značaj Applea kao zainteresirane strane u postupku, kao i procijenjenog iznosa zabranjene državne potpore. Ukratko, odluka EK-a nije samo zanimljiva u pravnom smislu, s obzirom na to da zapravo predstavlja

\footnotetext{
$90 \quad$ Vidjeti Odluku EK-a, para. 346.-359.

91 Vidjeti Odluku EK-a, para. 365.-366.

92 Vidjeti Odluku EK-a, para. 407.

93 Vidjeti Odluku EK-a, para. 409.

Vidjeti Odluku EK-a, para. 410.
} 
pionirsko tumačenje čl. 107. UFEU-a kao pravnog temelja za primjenu načela neovisnosti u svim državama članicama, ${ }^{95}$ nego ima i kompleksnu ekonomsku i političku dimenziju. Iako analiza potonjih aspekata prelazi granice ovog rada, vrijedi podcrtati kako se predmetna odluka, kao i odluke EK-a donesene u nekoliko srodnih postupaka, često promatra u kontekstu pogoršanih trgovinskih odnosa između EU-a i SAD-a. U tom smislu američka je vlada u veoma kratkom roku objavila radni dokument u kojem kritizira novi pristup EK-a, posebno tegoban za poduzeća sa sjedištem u SAD-u. ${ }^{96} \mathrm{Ni}$ u okrilju Unije odluka EK-a nije naišla na jednoznačnu podršku. Naime, kao što je već naznačeno supra (poglavlje 2.), široka primjena pravila o državnim potporama izaziva negativne reakcije onih država članica koje su posebno zabrinute za gubitak "poreznog suvereniteta", tj. sužavanja prostora za stvaranje kompetitivnijeg gospodarskog okvira s pomoću mjera porezne politike.

S druge strane, pravne prijepore koji proizlaze iz slučaja Apple u konačnici će razriješiti Sud EU-a. Naime, tužbe kojima se traži poništenje predmetne odluke EK-a podnijeli su krajem 2016. godine i Republika Irska i Apple grupa te se u idućem razdoblju očekuje pravorijek Općeg suda u ovim predmetima. ${ }^{97}$

Republika Irska i Apple, u svojstvu tužitelja, iznijeli su niz tužbenih razloga, uključujući i tvrdnje o bitnim povredama postupka te povredi prava na dobru upravu sadržanog u čl. 41. Povelje Europske unije o temeljnim pravima. ${ }^{98}$ Međutim, za potrebe ovog rada najzanimljivijim se čine tvrdnje tužitelja kako je Europska komisija pogrešno primijenila materijalno pravo pri ocjeni o dodjeli zabranjene državne potpore. Pritom je korisno razlučiti četiri osnovna argumenta, koja se detaljnije analiziraju u nastavku, polazeći od tužbenih navoda, dosadašnje prakse EK-a te stajališta iznesenih u znanstvenoj i stručnog literaturi.

\subsection{STATUS NAČELA NEOVISNOSTI U SVJETLU IRSKOG UNUTARNJEG PRAVA}

Prvo, tužitelji osporavaju utvrđenja EK-a o pravnom statusu načela neovisnosti. Tako irske vlasti ističu da načelo neovisnosti, sve do 2010. godine, uopće nije bilo ugrađeno u irsko porezno pravo te ne postoji pravni temelj za primjenu pravila o transfernim cijenama, poput onih sadržanih u OECD-ovim Smjernicama. ${ }^{99}$ Rječnikom prava državnih potpora EU-a, načelo neovisnosti ne može biti dio referentnog okvira za provedbu testa selektivnosti, čak i ako se prihvati stav EK-a da referentni okvir čini cjelokupan korpus irskih pravila o oporezivanju

95 Usp. Verhagen, H. L. E., State Aid and Tax Rulings - An Assessment of the Selectivity Criterion of Article 107(1) of the TFEU in Relation to Recent Commission Transfer Pricing Decisions, European Taxation, vol. 57, br. 7/2017., Journals IBFD.

96 Detaljan prikaz kritika američkog Ministarstva financija dostupan je ovdje: https://www.treasury.gov/resource-center/taxpolicy/treaties/Documents/White-Paper-State-Aid.pdf. Pristupljeno 10. studenog 2017.

97 Predmet T-778/16: Tužba podnesena 9. studenoga 2016. - Irska protiv Komisije, OJ C 38, 6. 2. 2017., str. 35.-36. i predmet T-892/16: Tužba podnesena 19. prosinca 2016. - Apple Sales International i Apple Operations Europe protiv Komisije, str. OJ C 53, 20. 2. 2017., str. 37.-39.

Riječ je o postupcima u kojima Sud EU-a, sukladno čl. 263. UFEU-a, ocjenjuje zakonitost akata institucija Unije. Nadležnost Općeg suda za odlučivanje u ovim postupcima propisana je u čl. 256. UFEU-a. 
dobitka. ${ }^{100}$ Prema irskim vlastima, pravila mjerodavna za utvrđivanje oporezive dobiti nerezidenata, poput društava ASI-ja i AOE-a, sadržana su isključivo u odjeljku 25. irskog Zakona o objedinjavanju poreznog sustava (engl. Tax Consolidation Act) iz 1997. godine, u kojem ne postoje odredbe o pripisivanju dobiti irskim podružnicama nerezidentnih društava analogne pravilima OECD-ovih Smjernica o pripisivanju dobiti SPJ-ima. Odgovor EK-a na ovu tvrdnju sadržan je već i u pobijanoj odluci. Ukratko, Komisija navodi da su irske porezne vlasti, u primjeni relevantnih unutarnjih pravila o oporezivanju dobiti nerezidenata, polazile od kriterija veoma sličnih onima iz OECD-ovih Smjernica te se može izvesti zaključak o implicitnoj primjeni načela neovisnosti. ${ }^{101} \mathrm{EK}$ to potkrepljuje i nizom poreznih mišljenja koje su donijela irska porezna tijela, u vezi s oporezivanjem podružnica nerezidentnih društava. ${ }^{102}$

\subsection{STATUS NAČELA NEOVISNOSTI U SVJETLU PRIMARNOG PRAVA EU-A}

U svakom slučaju, mnogo se važnijim čini pitanje statusa načela neovisnosti s aspekta primarnog prava EU-a. Naime, Republika Irska i Apple kao tužitelji tvrde kako je Komisija pogrešno primijenila pravila o državnim potporama, s obzirom na to da čl. 107. UFEU-a ne može predstavljati pravni temelj za primjenu načela neovisnosti. Vrijedi podsjetiti da se pobijana odluka u bitnome temelji na pravnom shvaćanju EK-a da sve države članice EU-a moraju primjenjivati načelo neovisnosti pri utvrđivanju porezne osnovice MNK-a - bez obzira na to je li ono implementirano u domaće pravo ili ne - s obzirom na to da takav zahtjev proizlazi iz čl. 107., st. 1. UFEU-a. ${ }^{103}$ U literaturi je primijećeno kako EK ovakvim tumačenjem UFEU-a, koje nije nedvosmisleno podržano u praksi Suda EU-a, načelu neovisnosti priznaje status autonomnog koncepta prava državnih potpora EU-a. ${ }^{104}$ Načelo neovisnosti u tom kontekstu dobiva funkciju zaštite tržišne utakmice na unutarnjem tržištu, tako da osigurava jednak (porezni) tretman između usporedivih poduzetnika. ${ }^{105}$ Stoga EK u pobijanoj odluci polazi od načela neovisnosti kao standarda za utvrđivanje odstupanja od referentnog porezno-pravnog okvira. $S$ obzirom na to da je Komisija utvrdila da porezni tretman Apple grupe nije bio u skladu s načelom neovisnosti, donesen je zaključak kako je riječ ujedno i o odstupanju od referentnog porezno-pravnog okvira, tj. prima faciae selektivnosti te o dodjeli ekonomske prednosti. ${ }^{106}$ Najslabija točka ovakvog rasuđivanja vezana je za nejasan sadržaj proklamiranog EU-ova na-

\footnotetext{
100 Jedan od istaknutih tužbenih razloga vezan je i za pogrešno utvrđenje referentnog okvira, koji bi, kako tvrdi Republika Irska u svojoj tužbi, morao biti znatno uži te sadržavati isključivo ona pravila irskog poreznog prava koja uređuju oporezivanje dobiti nerezidenata u Irskoj. Pitanje odabira referentnog porezno-pravnog okvira već je dotaknuto supra (poglavlje 4.2.). Dalje u radu se neće dalje analizirati ponajprije stoga što se pravno shvaćanje EK-a, kad je riječ o ovom pitanju, čini uvjerljivijim u odnosu na druge tužbene razloge.

101 Vidjeti Odluku EK-a, para. 371.

Vidjeti Odluua EK-a, para. 372. Zanimljivo je usporediti i mišljenje O’Shea, koji se, u svom komentaru odluke EK-a u predmetu Apple, poziva na druge odredbe irskog poreznog prava iz kojih proizlazi zaključak o (ograničenoj) primjeni načela neovisnosti pri utvrđivanju oporezive dobiti nerezidenata, čak i prije 2010. godine. Vidjeti O’Shea, T., An analysis of some Apple state aid arguments, Tax notes international, vol. 85, br. 13/2017, str. 1155.-1162.

103 Vidjeti supra, poglavlje 4.2.

104 Vidjeti Wattel, P. J., Stateless income, state aid and the (which?) arm's length principle, Intertax, vol. 44, br. 11/2016., str. 792.; Lovdahl Gormsen, L., op. cit., u bilj. 8, str. 380.-381.; Verhagen, op. cit., u bilj. 95, poglavlje 3.4.

105 Vidjeti detaljnije Wattel, P. J., op. cit., u bilj. 104.

106 Vidjeti supra, poglavlje 4.2.
} 
čela neovisnosti: koja konkretna pravila moraju primjenjivati porezna tijela država članica da bi ostvarila apstraktan zahtjev o jednakosti poduzetnika na unutarnjem tržištu, kako diktira "EU-ovo načelo neovisnosti”? U svojoj praksi, uključujući i odluku u predmetu Apple, EK izričito polazi od pravila sadržanih u OECD-ovim Smjernicama o transfernim cijenama. Kako ističe EK: “(T)e se smjernice ne odnose na sama pitanja u pogledu državnih potpora, ali je u njima sadržan međunarodni konsenzus o transfernim cijenama te se njima daju korisne smjernice poreznim upravama i multinacionalnim poduzećima kako osigurati da se metodologijom određivanja transfernih cijena dobivaju rezultati u skladu s tržišnim uvjetima. U skladu s time, ako je dogovor o određivanju transfernih cijena u skladu sa smjernicama iz Smjernica OECD-a o transfernim cijenama, uključujući smjernice za izbor najprikladnije metode, što dovodi do pouzdane procjene tržišnog rezultata, nije vjerojatno da će porezno mišljenje kojim se podržava takav dogovor uzrokovati državnu potporu." ${ }^{107}$ Međutim, OECD-ove Smjernice ne predstavljaju obvezujući pravni izvor međunarodnog poreznog prava te veći broj svjetskih država, uključujući i neke države članice EU-a, odstupaju u određenoj mjeri od preporuka sadržanih u navedenom dokumentu. ${ }^{108}$ Riječju, pitanje konkretizacije načela neovisnosti u obliku specifičnih pravila o transfernim cijenama i dalje predstavlja domaine réservé nacionalnog zakonodavca. ${ }^{109}$ Stoga ne čudi kako se i dio poreznih stručnjaka slaže s tvrdnjom Republike Irske i Applea kao tužitelja o nepostojanju pravnog temelja u UFEU-u za izravnu primjenu načela neovisnosti i pravila o transfernim cijenama. ${ }^{110}$

\subsection{METODOLOGIJA PRIMJENE NAČELA NEOVISNOSTI}

U tužbama Republike Irske i Applea protiv predmetne odluke EK-a nadalje je istaknuto da, čak i ako se prihvati Komisijino sporno tumačenje pravnog statusa načela neovisnosti, nalazi sadržani u pobijanoj odluci nisu usklađeni s općeprihvaćenom metodologijom primjene ovog načela, napose imajući u vidu cjelokupni činjenični supstrat. Ovaj dio tužbe zapravo se svodi na klasični spor o transfernim cijenama (engl. transfer pricing dispute), tj. o načinu pripisivanja prihoda i rashoda pojedinim subjektima unutar grupe povezanih društava. Kako je istaknuto supra (poglavlje 4.2.), za ocjenu EK-a o selektivnosti predmetnih akata irskih poreznih tijela ključna je bila analiza mogu li se autorske naknade koje ubiru društva ASI i AOE pripisati njihovim irskim SPJ-ima. Provedbom tzv. funkcionalne analize Europska komisija je izvela zaključak da je rezultat alokacije dobiti Apple grupe utjelovljen u poreznim mišljenjima izdanim 1991. i 2007. godine nesuglasan s načelom neovisnosti jer je barem dio autorskih naknada u pitanju trebao biti pripisan irskim SPJ-ima.

Već i tijekom postupka koji je prethodio donošenju pobijane odluke irske porezne vlasti i Apple osporavali su ovakav zaključak EK-a. Njihovi se protuargumenti, potkrijepljeni i s nekoliko ad hoc elaborata o transfernim cijenama, mogu sažeti na sljedeći način: (i) nematerijalna

107 Europska komisija, op. cit., u bilj. 26.

108 Detaljnije o pravnoj prirodi OECD-ovih Smjernica v. Wittendorf, J., Transfer Pricing and the Arm's Length Principle in International Tax Law, Kluwer Law International, Alphen aan den Rijn, 2010., str. 246.-248.

109 Usp. Luja, op. cit., u bilj. 33, str. 385.

110 Vidjeti posebno Lovdahl Gormsen, op. cit., u bilj. 8, str. 380.-381.; Verhagen, op. cit., u bilj. 95, poglavlje 3.4.; Cachia, op. cit., u bilj. 6., str. 32.-35. 
imovina i marketinške aktivnosti, koji su ključni za stvaranje vrijednosti Appleovih proizvoda i usluga, razvijaju se i upravljaju izvan Irske, točnije u SAD-u, u okviru krovnog društva Apple Inc., koje je ujedno i isključivi nositelj predmetnih prava intelektualnog vlasništva; ${ }^{111}$ (ii) funkcije irskih SPJ-a društava ASI-ja i AOE-a isključivo su rutinske naravi, a ključne strateške i komercijalne odluke, uključujući i odluke o sklapanju ugovora o podjeli troškova, donose uprave ovih društava, čiji se sastanci održavaju isključivo u SAD-u. ${ }^{112}$

Nadalje, tužitelji osporavaju nalaze EK-a vezane za neispravnu primjenu metode transakcijske neto marže od strane irskih poreznih vlasti. Ukratko, ukazuju na činjenice koje idu u prilog ispravnosti metodologije utjelovljenoj u poreznim mišljenjima iz 1991. i 2007. godine. U tom smislu vrijedi posebno ukazati na elaborate o transfernim cijenama podnesene kao dokazni materijal tijekom postupka EK-a, u kojima se objašnjava svrsishodnost odabira irskih SPJ-a kao testiranih strana za provedbu metode transakcijske neto marže te se tvrdi kako je procjena neto marže, pa time i oporezive dobiti irskih SPJ-a, u potpunom suglasju s preporukama OECD-ovih Smjernica. ${ }^{113}$

Kao i kod svakog spora o transfernim cijenama, riječ je o prijeporima visoke razine sofisticiranosti, čije rješenje zahtijeva duboko razumijevanje specifične materije pripisivanja prihoda i rashoda SPJ-ima. Rasuđivanje EK-a u dijelu pobijane odluke koji se odnosi na metodologiju transfernih cijena podvrgnuto je žestokim kritikama jednog broja poreznih stručnjaka. Posebno je naglašeno da EK veoma strogo tumači pravila o transfernim cijenama utjelovljena u OECD-ovim Smjernicama te na prvi pogled ne ostavlja mnogo prostora poreznim tijelima država članica da dođu do drukčijeg zaključka o ispravnoj alokaciji prihoda i rashoda unutar grupe povezanih društava. ${ }^{114} \mathrm{~S}$ druge strane, u međunarodnom je poreznom pravu odavno poznato kako transferne cijene nisu egzaktna znanost, nego je dostatno utvrditi cijene/uvjete koji predstavljaju dovoljno pouzdanu aproksimaciju cijena/uvjeta kakvi bi postojali između nepovezanih osoba. Vrijedi naglasiti da je mogućnost uporabe tzv. raspona transfernih cijena izričito priznata i u OECD-ovim Smjernicama. ${ }^{115}$

Čini se, međutim, da je strah od Komisijina prerevnog ispitivanja prakse transfernih cijena pro futuro pretjeran, bar ako uzmemo u obzir sve posebnosti Apple slučaja. Prvo, Komisija je, kao što je već istaknuto i supra, u Obavijesti o pojmu državnih potpora iz 2016. godine izričito pojasnila da svi rezultati koji se, u skladu s OECD-ovim Smjernicama, mogu smatrati pouzdanima najvjerojatnije neće predstavljati problem s aspekta državnih potpora. Drugo, aktualne istrage EK-a u vezi s poreznim mišljenjima i APA sporazumom isključivo su usmjerene na najočitije devijacije od načela neovisnosti. ${ }^{116} \mathrm{U}$ tom je smislu ključno podsjetiti na nekoliko činjeničnih aspekata slučaja Apple koji su u velikoj mjeri usmjerili rasuđivanje EK-a: (i) irska porezna tijela donijela su obvezujuća mišljenja unatoč izostanku relevantne dokumen-

\footnotetext{
111 Vidjeti Odluka EK-a, para. 162.-164. i para. 185.

112 Vidjeti Odluka EK-a, para. 195.

113 Vidjeti Odluka EK-a, para. 167.-172.

114 Vidjeti Luja, op. cit., u bilj. 33, str. 385.; Rossi-Maccanico, op. cit., u bilj. 11, str. 73.-74.; Lovdahl Gormsen, op. cit., u bilj. 8, str. 381.; De Broe, op. cit., u bilj. 24, str. 292.

115 Vidjeti OECD, op. cit., u bilj. 34., para. 3.55.

116 Vidjeti DG COMP Working Paper on State Aid and Tax Rulings, dostupno na: http://ec.europa.eu/competition/state-aid/ legislation/working-paper-tax-rulings.pdf. Pristupljeno 11. rujna 2017., para. 23.; Kardachaki, A., van Hulten, M.J., (2017). Report on the EUCOTAX Conference 'State Aid, Intangibles and Rulings', EC Tax Review, vol. 26, br. 5/2017., str. 285.
} 
tacije koja bi omogućila objektivnu ocjenu alokacijskog ishoda (npr. elaborat o transfernim cijenama, primjerak ugovora o podjeli troškova i sl.); (ii) prvo obvezujuće mišljenje doneseno je 1991. godine te se primjenjivalo na izračun oporezive dobiti društava ASI-a i AOE-a gotovo šesnaest godina, bez ikakvih izmjena; (iii) iz dokumentacije na temelju koje su irska porezna tijela donijela prvo obvezujuće mišljenje vidljivo je da predstavnici Applea dovode u vezu izračun dobiti grupe oporezive u Irskoj s daljnjim investicijskim aktivnostima, uključujući i zapošljavanje, u toj državi. ${ }^{117}$ Ukratko, u predmetnom je slučaju postojalo više indikatora diskrecijskog postupanja poreznih tijela, bez pouzdane metodološke podloge utvrđivanja porezne osnovice. ${ }^{118}$ Pritom vrijedi naglasiti da posljednjih dvadesetak godina u području transfernih cijena obilježava razvoj i dokumentacijskih zahtjeva koje većina država postavlja pred MNK-e i pravila postupanja poreznih tijela pri izdavanju poreznih mišljenja i APA sporazuma, upravo s ciljem osiguravanja što je moguće preciznijeg rezultata u svjetlu načela neovisnosti. ${ }^{119}$

\section{ZAKLJUČAK}

Odluka Europske komisije u predmetu Apple, potanko analizirana u ovom radu, predstavlja simbol dosad neviđenog aktivizma u primjeni prava državnih potpora EU-a kao alata za suzbijanje tzv. agresivnog poreznog planiranja trgovačkih društava. U ime svetog cilja jednakosti poduzetnika na unutarnjem tržištu Europska komisija u predmetnoj je odluci te u drugim srodnim postupcima (npr. slučajevi Fiat, Starbucks, Amazon), inaugurirala pionirsko tumačenje čl. 107. UFEU-a kao pravnog temelja za primjenu tzv. načela neovisnosti u svim državama članicama. Ukratko, EK polazi od pretpostavke da države članice mogu primjenom pravila o alokaciji prihoda i rashoda pojedinim MNK-ima dodijeliti nepoštenu prednost u odnosu na druge sudionike na unutarnjem tržištu te time područje transfernih cijena, koje je dosad bilo domena isključivo poreznih stručnjaka, ulazi u obuhvat prava državnih potpora. Kako primjećuje Wattel, načelo neovisnosti u tom kontekstu dobiva novu funkciju i postaje dio prava tržišnog natjecanja EU-a. ${ }^{120}$ To pred MNK-ove kao porezne obveznike, njihove savjetnike i porezna tijela država članica postavlja nove izazove: u primjeni pravila o transfernim cijenama više nije dovoljno zadovoljiti se alokacijskim ishodom koji je prihvatljiv iz interne perspektive; naprotiv, potrebno je napraviti nekoliko dodatnih koraka u analizi kako bi se utvrdilo suglasje s kriterijima koje, prema tumačenju EK-a, nameće pravo državnih potpora. S obzirom na to da Komisijino tumačenje načela neovisnosti polazi od preporuka sadržanih u OECD-ovim Smjernicama o transfernim cijenama, ovaj dokument u opisanom novom kontekstu EU-a dobiva i mnogo veću ulogu od kompendija "najboljih praksi”, kakvu je imao prema tradicionalnom shvaćanju pravne znanosti.

117 Općenito o kritici obvezujućih poreznih mišljenja kao oblika "dogovaranja” poreznih tijela i poreznih obveznika v. Lang, M., Tax Rulings and State Aid Law, British Tax. Review, br. 3, 2015., str. 395.

118 Usp. O’Shea, T., op. cit. U tom smislu moguće je i povući paralelu s prijašnjom praksom EK-a u istragama poreznih akata u svjetlu prava državnih potpora. Detaljnije v. Luja, op. cit., u bilj. 33, str. 384.

119 Dovoljno je upozoriti na temeljne postavke novog normativnog okvira transfernih cijena u Republici Hrvatskoj. Vidjeti npr. čl. 47.b Pravilnika o porezu na dobit, Narodne novine, broj 95/2005 - 1/2017; čl. 101.-122. Pravilnika o automatskoj razmjeni informacija u području poreza, Narodne novine, broj 18/2017; Pravilnik o postupku sklapanja prethodnog sporazuma o transfernim cijenama, Narodne novine, broj 42/2017. 
Dakako, gore ocrtano rasuđivanje EK-a u idućem će, vjerojatno višegodišnjem razdoblju, biti podvrgnuto sveobuhvatnoj analizi od strane Suda EU-a kao jedinog ovlaštenog tumača prava Unije. Većina razloga iz kojih Republika Irska, kao adresat odluke te Apple kao zainteresirana strana u postupku, pobijaju odluku EK-a već je detaljno obrazložena tijekom postupka Komisije, što omogućuje kritičku analizu temeljnih pravnih prijepora. Iako bi prejudiciranje konačne odluke EK-a bilo nalik gledanju u kristalnu kuglu, u radu smo pokušali barem naznačiti relativnu snagu argumenata tužitelja s jedne te EK-a kao tuženika s druge strane. Čini nam se kako se temeljna slabost nalaza Komisije krije u nametanju odgovornosti jednoj državi (Irskoj) za konačni porezni rezultat koji je posljedica interakcije poreznih sustava bar dviju država; preciznije, glavni oslonac Appleove porezne strategije uopće nije vezan za pravila o transfernim cijenama, nego za postizanje tzv. dvostruke nerezidentnosti društava ASI-ja i AOE-a; teško je zamisliti da bi Komisija uopće pokrenula postupak da je SAD navedena društva tretirao kao američke porezne rezidente te oporezovao njihove prihode od autorskih naknada. Drugim riječima, porezno planiranje Applea nije toliko problematično s aspekta irskog unutarnjeg prava - u okviru kojeg isključivo valja tražiti referentni okvir za analizu selektivnosti - nego s aspekta nepodudarnosti pravila irskog i američkog poreznog prava. Međutim, porezni tretman koji je posljedica nepodudarnosti nacionalnih poreznih sustava, tj. izostanka harmonizacije ako se krećemo isključivo u okvirima unutarnjeg tržišta EU-a, ne ulazi u obuhvat kontrole s aspekta državnih potpora jer je vezan za vršenje suverene državne vlasti u području oporezivanja. U tom smislu, pristup EK-a doista je upitan s aspekta poštovanja suverenosti država članica kad je posrijedi oporezivanje dobiti trgovačkih društava. ${ }^{121}$

Stoga u konačnici i odluka EK-a u predmetu Apple, bez obzira na konačno viđenje Suda EU-a o njezinoj valjanosti, služi kao još jedan podsjetnik ključnog problema međunarodnog i europskog poreznog prava: u okvirima globalne mobilnosti faktora proizvodnje i rapidnog tehnološkog napretka, jedini održivi način suzbijanja neželjenih shema poreznog planiranja krije se u jačoj harmonizaciji nacionalnih poreznih sustava, napose s ciljem izbjegavanja potencijalnih nepodudarnosti (npr. dvostruka nerezidentnost, hibridni aranžmani i sl.). Ako se zadržimo na užem kontekstu EU-a, umjesto posezanja za inovativnim interpretacijama prava državnih potpora dugoročno i mnogo poželjnije rješenje krije se u harmoniziranom sustavu oporezivanja MNK-a, ma s kolikom se skepsom gleda na postizanje konsenzusa svih država članica. ${ }^{122}$

\section{LITERATURA}

\section{A) KNJIGE I ČLANCI}

1. Arbutina, H., Određenje osobnog i predmetnog obuhvata porezne obveze pri oporezivanju dohotka i dobiti, Zbornik Pravnog fakulteta u Zagrebu, vol. 47, br. 1-2/1997., str. 159.-197.

2. Arbutina, H., Ott K., Porezni leksikon s višejezičnim rječnikom: engleski, hrvatski, francuski, njemački, španjolski, Institut za javne financije, Zagreb, 1999.

\footnotetext{
121 Usp. De Broe, op. cit., u bilj. 24, str. 291.; Luja, op. cit., u bilj. 33, str. 389.-390.

122 Detaljnije o prijedlogu modela tzv. zajedničke konsolidirane osnovice poreza na dobit (engl. Common Consolidated Corporate Tax Base; CCCTB) unutar EU-a v. Gadžo, S., op. cit., u bilj. 9, str. 769.-771.
} 
3. Ault, H. J.; Schön, W.; Shay, S. E., Base Erosion and Profit Shifting: A Roadmap for Reform, Bulletin for International Taxation, vol. 68, br. 6-7/2014.

4. Bratić, V., Porezni izdaci: teorijski pregled, Financijska teorija i praksa, vol. 30, br. 2., 2006., str. 113.-127.

5. Cachia, F., Analysing the European Commission's Final Decisions on Apple, Starbucks, Amazon and Fiat Finance \& Trade, EC Tax Review, vol. 26, br. 1/2017., str. 23.-35.

6. Čičin-Šain, N., Novi pristup u određenju dobiti stalne poslovne jedinice - pristup OECD-a te implikacije za hrvatsko porezno pravo, Zbornik Pravnog fakulteta Sveučilišta u Rijeci, vol. 37, br. 3, 2016., str. 1231.-1249.

7. De Broe, L., The State Aid Review against Aggressive Tax Planning: 'Always Look a Gift Horse in the Mouth, EC Tax Review, vol. 24, br. 6/2015., str. 290.-293.

8. Easson, A., Thurony, V., Fiscal Transparency, u: Thurony, V., Tax law design and drafting (vol. 2.), International Monetary Fund, Washington, 1998., str. 925.-968.

9. Eden, L., Taxing Multinationals: Transfer Pricing and Corporate Income Taxation in North America, University of Toronto Press, Toronto, 1998.

10. Fleming, J. C., The EU Apple Case: Who Has a Dog in the Fight?, Tax Notes, vol. 154, br. 2/2017., str. 251.-256.

11. Gadžo, S., Prilog istraživanju sadržaja načela pravednosti kao kriterija evaluacije normi međunarodnog poreznog prava, Pravni vjesnik, vol. 31, br. 2/2015., str. 131.-156.

12. Gadžo, S., Nematerijalna imovina multinacionalnih korporacija u kontekstu međunarodnog poreznog prava, Zbornik Pravnog fakulteta u Zagrebu, vol. 65, br. 5/2015., str. 743.-773.

13. Gadžo, S., Međunarodno porezno planiranje multinacionalnih korporacija s posebnim osvrtom na ulogu nematerijalne imovine (II.), Pravo i porezi, br. 4/2016.

14. Kardachaki, A., Van Hulten, M. J. (2017), Report on the EUCOTAX Conference 'State Aid, Intangibles and Rulings', EC Tax Review, vol. 26., br. 5/2017.

15. Kerschner, I., Stiastny, M., The Experience with Advance Pricing Agreements, Intertax, vol. 41, br. 11/2013., str. 588.-593.

16. Lang, M., Tax Rulings and State Aid Law, British Tax Review, br. 3, 2015., str. 391.-395.

17. Lang, M., State Aid and Taxation: Selectivity and Comparability Analysis, u: Richelle, I., et al. (ur.), State Aid Law and Business Taxation, Springer, Berlin, 2016.

18. Li, J., Global profit split: An evolutionary approach to international income allocation, Canadian Tax Journal, vol. 50, br. 3/2002.

19. Lovdahl Gormsen, L., EU State Aid Law and Transfer Pricing: A Critical Introduction to a New Saga, Journal of European Competition Law \& Practice, vol. 7., br. 6/2016., str. 369.-382.

20. Luja, R. H. C., Assessment and recovery of tax incentives in the EC and the WTO: a view on state aids, trade subsidies and direct taxation, Intersentia, Antwerpen, 2003.

21. Luja, R. H. C., (Re)shaping Fiscal State Aid: Selected Recent Cases and Their Impact, Intertax, vol. 40, br. 2, 2012., str. 120.-131.

22. Luja, R. H. C., Will the EU's State Aid Regime Survive BEPS?, British Tax Review, br. 3/2015., str. 379.-390.

23. Maitrot de la Motte, A., The Recovery of the Illegal Fiscal State Aids: Tax Less to Tax More, EC Tax Review, vol. 26, br. 2/2017., str. 75.-88.

24. Mamut, M. A., The State Aid Provisions of the TFEU in Tax Matters, u: Lang, M., et al. (ur.), Introduction to European Tax Law on Direct Taxation, Linde, Beč, 2010., str. 82.-96. 
25. Martinović, Ž., Ključne točke OECD-ova Akcijskog plana o eroziji porezne osnovice i alokaciji profita (Base Erosion and Profit Shifting - BEPS), Porezni vjesnik, br. 10/2015., str. 100.-112.

26. Micheau, C., State Aid and Taxation in EU Law, u: E. Szyszczak (ur.), Research Handbook on European State Aid Law, Edward Elgar, Cheltenham, 2011.

27. Mijatović, N., Pošteno oporezivanje: nove mjere Europske komisije za borbu protiv porezne utaje, Porezni vjesnik, br. 4/2016.

28. O'Shea, T., An analysis of some Apple state aid arguments, Tax notes international, vol. 85, br. 13/2017., str. 1155.-1162.

29. Owens, J., The Taxation of Multinational Enterprises: An Elusive Balance, Bulletin for International Taxation, vol. 67., br. 8/2013., str. 441.-445.

30. Petrović, S., Liszt, M., Kriteriji za dodjelu dopuštenih državnih potpora, u: Čulinović Herc, E. et al. (ur.), Financiranje, upravljanje i restrukturiranje trgovačkih društava u vrijeme recesije, Rijeka, Pravni fakultet Sveučilišta u Rijeci, 2011., str. 27.-68.

31. Rogić Lugarić, T., Porezna tijela i porezni obveznici: od policajca i lopova do suradnika, u: Koprić, I.; Musa, A.; Giljević, T. (ur.), Građani, javna uprava i lokalna samouprava: povjerenje, suradnja, potpora, Institut za javnu upravu, Zagreb, 2017., str. 341.-362.

32. Rogić Lugarić, T., Bogovac, J., Poreznopravni aspekti poreznih izdataka, Hrvatska i komparativna javna uprava, vol. 13., br. 4, 2013.

33. Rossi-Maccanico, P., Fiscal State Aids, Tax Base Erosion and Profit Shifting, EC Tax Review, vol. 24, br. 2, 2015., str. 63.-77.

34. Schön, W., Tax Legislation and the Notion of Fiscal Aid: A Review of 5 Years of European Jurisprudence, u: Richelle, I., et al. (ur.), State Aid Law and Business Taxation, Springer, Berlin, 2016.

35. Terra, B., Wattel, P. J., European Tax Law, Kluwer Law International, 2012.

36. Ting, A., iTax: Apple's International Tax Structure and the Double Non-Taxation Issue, British Tax Review, br. 1, 2014., str. 40.-71.

37. Verhagen, H. L. E., State Aid and Tax Rulings - An Assessment of the Selectivity Criterion of Article 107(1) of the TFEU in Relation to Recent Commission Transfer Pricing Decisions, European Taxation, vol. 57, br. 7/2017., Journals IBFD.

38. Wattel, P. J., Stateless income, state aid and the (which?) arm's length principle, Intertax, vol. 44, br. 11/2016., str. 791.-801.

39. Wittendorf, J., Transfer Pricing and the Arm's Length Principle in International Tax Law, Kluwer Law International, Alphen aan den Rijn, 2010.

40. Žunić Kovačević, N., Prethodna obvezujuća porezna mišljenja - novi institut hrvatskog poreznog postupka, Zbornik Pravnog fakulteta Sveučilišta u Rijeci, vol. 37, br. 1/2016.

\section{B) POPIS PROPISA, AKATA I SUDSKIH ODLUKA}

1. Europska komisija (1998), Obavijest Komisije o primjeni propisa o državnim potporama na mjere koje se odnose na izravno oporezivanje poduzetnika, SL C 384, 10. 12. 1998., str. 3.-9.

2. Europska komisija (2016), Obavijest Komisije o pojmu državne potpore iz članka 107. stavka 1. Ugovora o funkcioniranju Europske unije, SL C 262, 19. 7. 2016.

3. Odluka Komisije (EU) 2016/1699 od 11. siječnja 2016. o programu državnih potpora u pogledu izuzeća od oporezivanja viška dobiti SA.37667 (2015/C) (ex 2015/NN) koji je provela Belgija, SL L 260, 27. 9. 2016., str. 61.-103. 
4. Odluka Komisije (EU) 2016/2326 od 21. listopada 2015. o državnoj potpori SA.38375 (2014/C ex 2014/NN) koju je dodijelio Luksemburg u korist društva Fiat, OJ L 351, 22. 12. 2016., str. 1.-67.

5. Odluka Komisije (EU) 2017/1283 od 30. kolovoza 2016. o državnoj potpori SA.38373 (2014/C) (ex 2014/NN) (ex 2014/CP) koju je provela Irska za društvo Apple, SL L 187, od 19. srpnja 2017., str. 1.- -110 .

6. Odluka Komisije (EU) 2017/502 od 21. listopada 2015. o državnoj potpori SA.38374 (2014/C, ex 2014/NN) koju je Nizozemska provela u korist Starbucksa, SL L 83, 29. 3. 2017., str. 38.-115.

7. Presuda Suda EU-a od 15. studenog 2011., združeni predmeti European Commission (C-106/09 P) and Kingdom of Spain (C-107/09 P) v Government of Gibraltar and United Kingdom of Great Britain and Northern Ireland, EU:C:2011:732.

8. Presuda Suda EU-a od 22. lipnja 2006., Kingdom of Belgium (C-182/03) and Forum 187 ASBL (C217/03) v Commission of the European Communities, EU:C:2006:416, ECR 2006 I-05479.

9. Presuda Suda EU-a od 23. veljače 1961., Gezamenlijke Steenkolenmijnen, Case 30/59, EU:C:1961:2.

10. Ugovor o funkcioniranju Europske unije, SL C 202, od 7. lipnja 2016., str. 1.-388.

\section{C) MREŽNI IZVORI}

1. DG COMP Working Paper on State Aid and Tax Rulings, dostupno na: http://ec.europa.eu/competition/state_aid/legislation/working-paper-tax-rulings.pdf. Pristupljeno 11. rujna 2017.

2. European Commission (2016), State aid: Ireland gave illegal tax benefits to Apple worth up to $€ 13$ billion, dostupno na: http://europa.eu/rapid/press-release-IP-16-2923-en.htm. Pristupljeno 11. listopada 2017.

3. http://revenuesandprofits.com/how-apple-makes-money/. Pristupljeno 10. lipnja 2017.

4. http://www.nasdaq.com/symbol/aapl. Pristupljeno 3. listopada 2017.

5. http://www.oecd.org/tax/treaties/multilateral-convention-to-implement-tax-treaty-related-measures-to-prevent-beps.htm. Pristupljeno 10. studenog 2017.

6. https://assets.kpmg.com/content/dam/kpmg/xx/pdf/2016/08/etf-300-state-aid-decision-in-theapple-case.pdf. Pristupljeno 18. lipnja 2017.

7. https://www.icij.org/project/luxembourg-leaks. Pristupljeno 18. lipnja 2017.

8. https://www.treasury.gov/resource-center/tax-policy/treaties/Documents/White-Paper-State-Aid. pdf. Pristupljeno 10. studenog 2017.

9. The Permanent Subcommittee On Investigations (2013), Offshore Profit Shifting and the U.S. Tax Code - Part 2 (Apple Inc.), dostupno na: http://www.hsgac.senate.gov/subcommittees/investigations/hearings/offshore-profit-shifting-and-the-us-tax-code-part-2. Pristupljeno 12. lipnja 2017.

10. U.S. Department of the Treasury, The European Commission's recent state aid investigations of transfer pricing rulings (white paper), dostupno na: https://www.treasury.gov/connect/blog/Pages/Treasury-Releases-White-Paper-on-European-Commission\%E2\%80\%99s-State-Aid-Investigations-into-Transfer-Pricing-Rulings.aspx. Pristupljeno 10. listopada 2017. 


\section{TAXATION OF MULTINATIONAL COMPANIES IN LIGHT OF THE EU STATE AID LAW: THE ANALYSIS OF THE “APPLE CASE”**}

\section{Summary}

The paper analyses the most important legal aspects of the recent European Commission's decision regarding the "Apple case". The decision, adopted in August 2016, breeds controversies, especially as to the innovative interpretation of the so-called arm's length principle and transfer pricing rules within the EU context. Legal reasoning of the Commission will be put to the judicial test by the Court of Justice of the European Union in the coming period. From a broader perspective, the Apple decision is tied to the current debates on "fairer" taxation of multinational companies. In this regard it is evident that the EU institutions are using state aid rules as instruments against the so-called aggressive tax planning. However, from the perspective of individual Member States this may be considered as an undue encroachment on their tax sovereignty. Against this backdrop, main findings of this paper may be useful for academics and practitioners dealing with neighbouring areas of tax law and state aid law.

Keywords: $\quad$ state aid law, Apple, corporate income tax, tax rulings, transfer pricing, international tax law

** This work was created with the support of the Croatian Science Foundation - project no. 9366, "Legal Aspects of Corporate Acquisitions and Restructuring of Knowledge-Based Companies". 